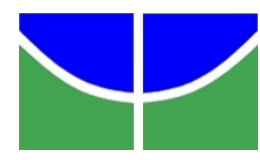

UNIVERSIDADE DE BRASÍLIA

INSTITUTO DE PSICOLOGIA

PROGRAMA DE PÓS-GRADUAÇÃO EM PSICOLOGIA CLÍNICA E CULTURA

CONSTRUÇÃO DAS MASCULINIDADES EM DEPRESSÃO:

REVISÃO DE LITERATURA E ANÁLISE DE CASOS

Naiara Windmöller

Brasília - DF

2016 
UNIVERSIDADE DE BRASÍLIA

INSTITUTO DE PSICOLOGIA

PROGRAMA DE PÓS-GRADUAÇÃO EM PSICOLOGIA CLÍNICA E CULTURA

CONSTRUÇÃO DAS MASCULINIDADES EM DEPRESSÃO:

REVISÃO DE LITERATURA E ANÁLISE DE CASOS

\section{Naiara Windmöller}

Dissertação apresentada ao Instituto de Psicologia da Universidade de Brasília como requisito parcial para a obtenção de título de Mestra em Psicologia Clínica e Cultura.

Orientadora: Prof. Dra. Valeska Maria Zanello de Loyola

Brasília - DF

2016 


\section{UNIVERSIDADE DE BRASÍLIA \\ INSTITUTO DE PSICOLOGIA}

DISSERTAÇÃO DE MESTRADO APROVADA PELA SEGUINTE BANCA EXAMINADORA:

Profa. Dra. Valeska M. Zanello de Loyola - Presidente

Universidade de Brasília - UnB

Prof. Dr. Juan Guillermo Figueroa Perea - Membro Externo

Universidad Nacional Autónoma de México - UNAM

Profa. Dra. Isabela Machado da Silva - Membro Interno

Universidade de Brasília - UnB

Profa. Dra. Silvia Lordello - Membro Suplente

Universidade de Brasília - UnB 


\section{AGRADECIMENTOS}

Antes de tudo, agradeço a Clair, minha mãe, e ao Roland, meu pai, os quais foram fontes essenciais e inspiradoras ao longo do processo. Sou a grata a relação afetuosa e respeitosa construída, mas também, por, sempre, me incentivarem na busca por novos horizontes e caminhos na vida.

Com apreço e carinho, agradeço a Professora Valeska Zanello, minha orientadora. Sou grata à parceria entusiasmada e enérgica na pesquisa, bem como nas orientações e supervisões. Sempre, manteve a orientação criteriosa, além do mais, o exercício crítico, engajado e reflexivo da profissão.

Sou grata a professora Tânia Inessa e ao Professor e amigo José Bizerril pela carta de recomendação e o incentivo na pesquisa.

Ao CNPq que viabilizou este projeto por meio da bolsa de estudos concedida.

Às professoras Isabela Machado da Silva e Silvia Lordello, e ao professor Juan Guillermo Figueroa Perea da banca examinadora por aceitarem de prontidão o convite.

Ao pessoal da pesquisa, em especial, ao Fabiano Gomes pela recepção calorosa, competência e encaminhamento dos pacientes no hospital. E não posso deixar de agradecer aos meus interlocutores que conheci e entrevistei. Com muito respeito, agradeço, sobretudo, pela confiança depositada em mim.

Não posso claro, esquecer das colegas do grupo de pesquisa Saúde Mental e Gênero da Pós-Graduação, em especial: Aline Xavier, Gisele Dantas, Ioneide Campos, Mariana Pedrosa e Marizete Gouveia pelas discussões calorosas e pela rica troca de experiências. E não poderia deixar de mencionar: Carol Romero, Humberto Costa, Lipe de Baére e Mariana Borges. As alunas da graduação em psicologia: Bruna Maia e Jade Lage por realizarem a transcrição das entrevistas de forma rigorosa e competente. Além do mais, ao André Felipe, que apareceu surpreendentemente ao final da pesquisa e colaborou na transcrição de uma entrevista e relembramos o estágio em psicologia, o qual eu fui sua supervisora.

Ao pessoal da secretaria da Pós-Graduação de Psicologia Clínica e Cultura pela atenção. Em especial a Thamiris Rodrigues, pela excelência no atendimento. 
Ao meu irmão Daniel e aos familiares que estiveram presentes e foram fonte de apoio: Bete Gabbi, Taciana Mareth, Carla, Cecília, Claúdia, Dario, Felipe, Marise e Rony.

As colegas que se tornaram amigas, com as quais tive a honra de trabalhar: Kallyane Dantas, Núbia Lima, Stella Juliana e Stella Maris, que acompanharam todo o meu processo de ingresso no mestrado e sempre me incentivaram, com as quais aprendi muito sobre o trabalho interdisciplinar e as escolhas que tomamos na vida.

Aos/as amigos/as e colegas de profissão que me apoiaram no ingresso do mestrado: Amanda de Oliveira, Marianna Queiroz, João Antônio, Pedro de Luna e João Maia. E ao Pedro Gaspa pelo incentivo na pesquisa e pelo tempo que acompanhou este processo.

Ao apoio e ao carinho das grandes amigas: Aline Vieira, Cíntia Gomes de Sá, Christine Chagas, Luciane Ouriques, Nana Foster, Nina Ridd, Rosana Medeiros, Renata Camargo, Semíramis de Medeiros e Vívian Dayrell.

Aqueles e aquelas que cuidaram do meu corpo e da minha saúde mental com conhecimentos e saberes valiosos: Ângela Sá, Bodhigita, Flávia Miranda, Maria Orieta Porto, Marga, Silvia Macario, Max Xavier e Rafael Leal.

Aos que contribuíram, de forma valiosa, com análises e leitura do meu trabalho na fase final e ao apoio afetuoso: Rosana Medeiros, Vívian Dayrell, Lipe de Baére e Marcelo Rocha.

E por fim, ao Grupo Diálogo, e aos professores e as professoras da graduação em psicologia por terem contribuído para a minha reflexão crítica da profissão: Cláudia Feres, Cynthia Ciarallo, Eileen Flores, Fernando González Rey, Rogério Lopes de Souza e Valéria Mori.

A todos e a todas que acreditam no fortalecimento, que passa também pela consciência de gênero, e no engajar-se socialmente no exercício da psicologia: o meu Muito Obrigada! 
Windmöller, Naiara (2016). Construção das masculinidades em depressão: revisão de literatura e análise de casos. Dissertação de mestrado, Instituto de Psicologia, Universidade de Brasília, Brasília.

\section{RESUMO}

Diante da incipiência de pesquisas em saúde mental que levem em consideração o viés de gênero, a presente dissertação se propõe a discutir a "depressão masculina" seguindo os aportes teóricos dos estudos das masculinidades advindos dos movimentos e debates feministas. Estudos de gênero afirmam que a ideia de potência, de virilidade está no cerne da dominação masculina. E nesse sentido, os homens sofreriam, também, com esta dominação? $\mathrm{E}$ de que forma e por quais razões? A literatura tem feito a relação entre os fatores de risco e os fatores de proteção a saúde mental com as categorias analíticas de gênero e raça? No que diz respeito à depressão, esta foi construída como categoria, no ocidente, ao longo dos séculos e tem sido abordada em larga medida pelos grandes manuais psiquiátricos (DSM E CID). Diante de tais reflexões teóricas, o presente trabalho está constituído por dois artigos, os quais foram resultantes de duas etapas distintas da pesquisa. O primeiro artigo resulta de um levantamento bibliográfico e de uma revisão sistemática sobre o referido tema em duas das principais plataformas científicas brasileiras, a saber: LILACS e SciELO Brasil, entre os anos de 2003 a 2013. Foram encontrados na plataforma LILACS 1378 artigos e na base SciELO Brasil 386. Dentre os dezessete artigos analisados, enquadrados nos critérios de inclusão, a maioria foi de caráter epidemiológico e comparativo com as mulheres e foram quase inexistentes as pesquisas qualitativas com esse público. Além disso, as categorias analíticas tais como gênero e raça foram em sua maioria, menosprezadas pelos/as pesquisadores/as. Devido à inexistência de pesquisas qualitativas e que levassem em consideração as interseccionalidades referidas, o segundo artigo visou fomentar uma discussão sobre as masculinidades e a depressão, que ouvisse, então, as narrativas masculinas. Diante desse propósito, foi realizada uma pesquisa qualitativa, em que foram ouvidas e analisadas três histórias de vida de homens diagnosticados com depressão (sem comorbidades), em um hospital público em uma capital brasileira. Em todas as histórias narradas, percebe-se que falta a eles uma consciência de gênero no sentido de não percepção do sofrimento relacionado às normativas de gênero. Houve especificidades nos achados quanto à faixa etária $e$ interseccionalidades de classe e raça. Sobretudo, as queixas, em geral, se localizaram na esfera sexual e laborativa, seja pela falta do que não se pode ser/realizar no passado, marcada pelo pretérito imperfeito ou pela ruptura da idealização no presente. São afetos e vivências caracterizados pelo endurecimento do corpo e dos afetos, pela competição e comparação com outros homens, com tonalidades de culpa e fracasso. Diante dessa pesquisa, portanto, sugerese o investimento e o desenvolvimento de mais pesquisas que levem em consideração os aportes teóricos das masculinidades e que conversem com a psicologia clínica, e que podem ser efetivas e úteis para as políticas públicas de saúde mental e de saúde do homem no Brasil. Ademais, que possam romper com a psicologização e a essencialização do "masculino", ao considerar as contribuições dos estudos de gênero e das masculinidades.

Palavras-chave: Masculinidades. Depressão. Levantamento Bibliográfico. Histórias de Vida. 


\begin{abstract}
Given the paucity of mental health research that takes into account the gender bias, this thesis is to discuss the "male depression" according to the theoretical contributions from the studies of masculinities originated from feminist movements and debates. Gender studies claim that the power in the idea of manhood is at the heart of male dominance. In this sense, would men suffer too with this rule? How and for what reasons? Has the literature pointed out the relationship between risk factors and protective factors to mental health and the analytical categories of gender and race? As far as depression is concerned, it was built as a category in the West over the centuries and has been addressed largely by major psychiatric manuals (DSM and ICD). Given these theoretical reflections, this study is composed of two articles, resulting from two distinct stages of research. The first article originates from a literature survey and a systematic review on the topic in two main Brazilian scientific data bases, namely LILACS and SciELO Brazil between the years 2003 to 2013. LILACS platform provided 1378 articles and SciELO Brazil 386. Most of the seventeen articles analyzed, after passing the inclusion criteria, were of epidemiological character and comparative with women. Qualitative research with men was almost nonexistent. In addition, analytical categories such as gender and race were mostly overlooked by the researchers. Due to the absence of qualitative research that took into account those intersectionalities, the second article aimed to foster the discussion on masculinities and depression, having an ear to male narratives. With this purpose, a qualitative survey was conducted, in which three life stories were heard and analyzed of men diagnosed with depression (without comorbidities) in a public hospital in a capital city of Brazil. In all the stories it was clear that the men lack gender consciousness in the sense that they do not perceive the suffering generated by gender norms. There were specifics on the findings regarding age and class and race intersectionalities. Above all, complaints were generally related to sexual and productive work sphere, either because of not having done or been in the past, marked by the past continuous, or because of disruption of idealization in the present. Those are feelings and experiences characterized by hardening of the body and the emotions, by competition and comparison with other men, with shades of guilt and failure. It is suggested, therefore, investment on and development of further research that takes into account the theoretical contributions of masculinities, and that dialogues with clinical psychology. This research can be effective and useful for public policies on mental health and men's health in Brazil. Moreover, it can break the psychologizing and essentializing the "masculine", when considering the contributions of gender and masculinities studies.
\end{abstract}

Keywords: Masculinities. Depression. Bibliographical Survey. Life stories. 


\section{RESUMEN}

Delante de la insipiencia en investigaciones en salud mental que lleven en consideración la cuestión de género, la presente disertación se propone discutir la "depresión masculina" siguiendo los aportes teóricos de los estudios de las masculinidades derivadas de los movimientos y debates feministas. Estudios de género afirman que la idea de potencia, de virilidad está en el centro de la dominación masculina ¿Y en este sentido, los hombres sufrirían también con esta dominación?¿De qué forma y por cuales razones? ¿La literatura ha hecho la relación entre los factores de riesgo y los factores de protección a la salud mental con las categorías analíticas de género y de raza? En lo que dice respecto a la depresión, esta fue construida como categoría, en occidente, a lo largo de los siglos ha sido abordada en larga medida por los grandes manuales psiquiátricos (DSM y CID). Frente a tales reflexiones teóricas, el presente trabajo está constituido por dos artículos, los cuales fueron resultantes de dos etapas distintas del estudio. El primer artículo resulta de un levantamiento bibliográfico y de una revisión sistemática sobre el referido tema en dos de las principales plataformas científicas brasileñas, estas son: LILACS y SciELO Brasil, entre los años 2003 y 2013. Fueron encontrados en la plataforma LILACS 1378 artículos y en la base SciELO Brasil 386. Entre los diecisiete artículos analizados, encuadrados en los criterios de inclusión, la mayoría fue de caráctere pidemiológico y comparativo con las mujeres y fueron casi inexistentes las investigaciones cualitativas con ese público. Además de eso, las categorías analíticas tales como género y raza fueron en su mayoría, menospreciadas por los/las investigadores/as. Debido a la inexistencia de investigaciones cualitativas y que llevasen en consideración las interseccionalidades referidas, el segundo artículos buscó fomentar una discusión sobre las masculinidades y la depresión, que escuchara, entonces, las narrativas masculinas. Frente a este propósito, fue realizada una investigación cualitativa, en que fueron oídas y analizadas tres historias de vida de hombres diagnosticados con depresión (sin comorbilidades), en un hospital público en una capital brasileña. En todas las historias narradas, se percibe que les falta una conciencia de género en el sentido dela no percepción del sufrimiento relacionado a las normativas de género. Hubo especificidades en lo encontrado en cuanto al rango etario e interseccionalidades de clase y raza. Principalmente, las quejas, en general, se localizaron en la esfera sexual y laboral, sea por la falta de lo que no se puede ser/realizar en el pasado, marcada por el pretérito imperfecto o por la ruptura de la idealización en el presente. Son afectos y vivencias caracterizados por el endurecimiento del cuerpo y de los afectos, por la competición y comparación con otros hombres, con tonalidades de culpa y fracaso. Frente a esta investigación por lo tanto, se sugiere la inversión y desarrollo de más investigaciones que lleven en consideración los aportes teóricos de las masculinidades y que conversen con la psicología clínica, que en ocasiones pueden ser efectivas y útiles para las políticas públicas de salud mental y de la salud del hombreen en el Brasil. Además, que puedan romper con la psicologización y la esencialización del masculino, al considerar las contribuciones de los estudios de género y de las masculinidades.

Palabras Clave: Masculinidades. Depresión. Levantamiento Bibliográfico. Historias de Vida. 
SUMÁRIO

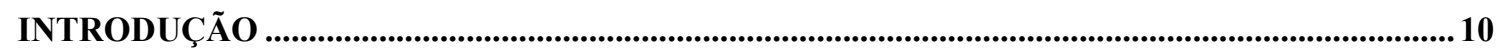

ARTIGO 1- DEPRESSÃO E MASCULINIDADES: UMA REVISÃO SISTEMÁTICA DA LITERATURA EM PERIÓDICOS BRASILEIROS .................................................................. 19

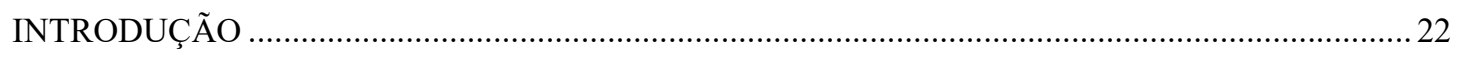

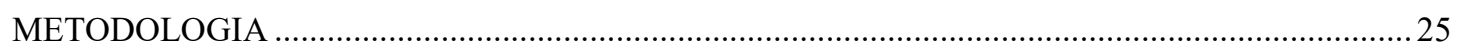

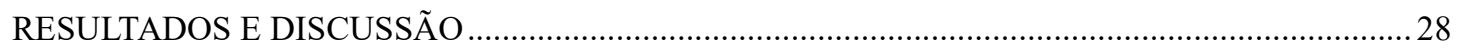

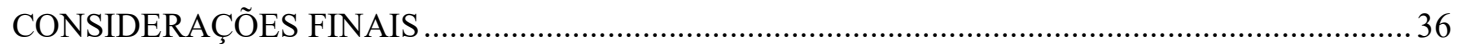

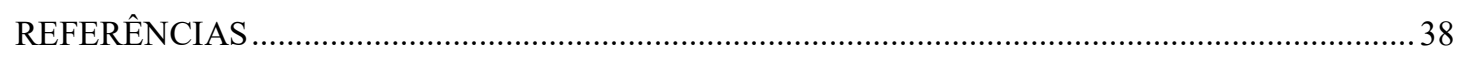

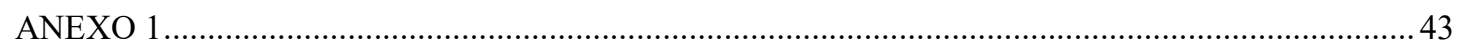

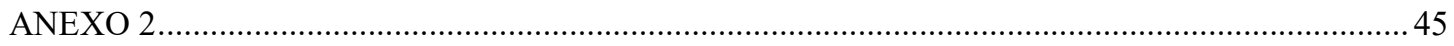

ARTIGO 2- DEPRESSÃO EM HOMENS: UMA LEITURA A PARTIR DAS

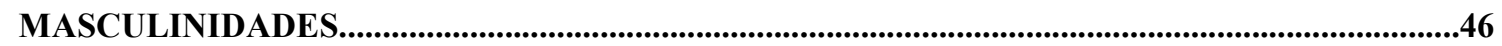

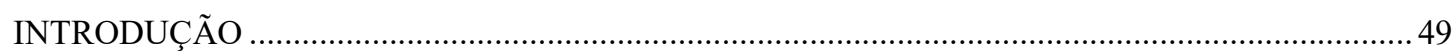

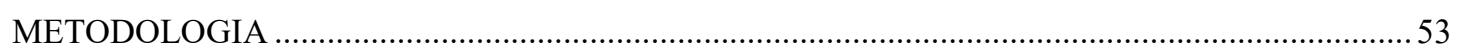

DEPRESSÃO EM HOMENS: MASCULINIDADES DESEMPODERADAS .......................................56

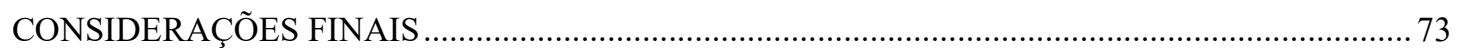

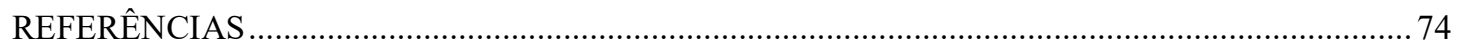

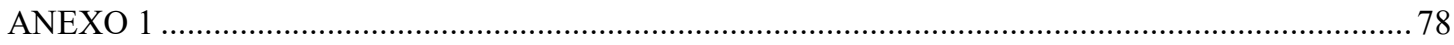

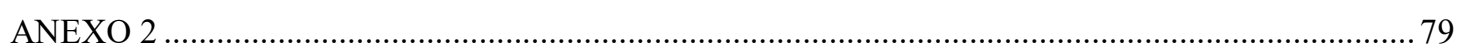

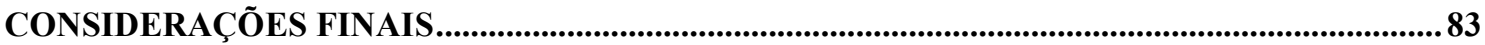

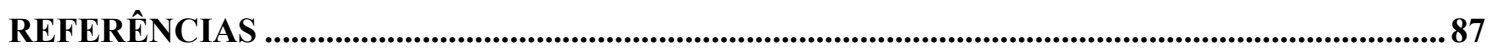




\section{INTRODUÇÃO}

\section{Trajetória contada no campo das masculinidades}

A produção de conhecimento, de longe, não é neutra, sobretudo, nos estudos de gênero. Implicar-se, posicionar-se e admitir meu lugar de fala como pesquisadora mulher e feminista faz parte da tomada de consciência de gênero e de transformação social também na pesquisa acadêmica.

Para tanto, o debate teórico acerca das masculinidades passa por reflexões e questionamentos oriundos dos estudos feministas. "Se a base da identidade de gênero é uma repetição estilizada de atos no tempo, e não uma identidade aparentemente homogênea" (Butler, 2011, p.70), então, de que modo o gênero é constituído através de atos corporais específicos, e que possibilidades existem para ocorrer uma transformação cultural através de tais atos? (Butler, 2011). E quando a história esconde em suas narrativas aquilo que poderia perturbar a ordem patriarcal? (Navarro, 2014).

Este projeto teve inicio, sem que eu soubesse, em 2011, quando fui nomeada e tomei posse no cargo de psicóloga em uma empresa pública do ramo eletricitário. Fui lotada na área ocupacional e atendia homens em sua grande maioria. No início, não sabia exatamente como poderia contribuir com aquele serviço, os atendimentos tratavam dos mais diversos assuntos, tais como: mediação de conflitos entre os funcionários, acidentes de trabalho e afastamentos para tratamento de saúde. Lembrome de alguns atendimentos que subitamente me inquietaram: de um homem que tentou se suicidar em que o principal motivo, segundo sua própria narrativa, foi por ter se endividado e não sabia como pagaria as contas e estava muito envergonhado perante sua família; de outro homem que fazia uso abusivo de álcool e outras substâncias psicoativas quando tinha frustrações amorosas, e que por esse motivo faltava muitas 
vezes o trabalho, e chegou a ser internado em instituição psiquiátrica para tratamento de saúde; e por fim de outro funcionário que estava fazendo uso abusivo de cocaína e ameaçava colegas no ambiente de trabalho. Logo fui percebendo que a saúde do trabalhador tem uma aproximação tênue com a saúde mental, o que me levou a ter inquietações do tipo: 1) "A subjetivação 'masculina' seria diferente da 'feminina' "?; 2) "Os homens teriam outras performances"?; 3) "Por quais vias subjetivas passaria o 'adoecimento masculino"?"; 4) "E se o gênero fosse visto e tratado como um dos fatores do adoecimento"?; 5) "As causas de afastamentos laborais (para tratamento de saúde mental) apresentavam relações como o fato de eles serem homens"?;

No início, a equipe era composta por duas psicólogas (incluindo a mim) e duas assistentes sociais, além de duas nutricionistas e dois médicos do trabalho. À medida que os projetos foram sendo implementados, principalmente pelas psicólogas e assistentes sociais, a área foi crescendo, e foi criada uma coordenação separada da área de recursos humanos, em que praticamente duplicamos a quantidade de profissionais dessas especialidades. Foi institucionalizada a área de qualidade de vida no trabalho e o serviço de clínica do trabalho pela psicologia e pelo serviço social.

Assim também, no último ano na companhia, coordenei aquela área e fiz parte da criação de alguns programas, só para citar um deles, foi criado o programa de prevenção e enfrentamento ao uso/abuso e dependência de álcool e/ou outras drogas com foco na abordagem de redução de danos. Na época, esse programa me pareceu um bom norte, por investir na lógica da prevenção, uma vez que a maioria dos afastamentos para tratamento de saúde acontecia em instituições psiquiátricas, custeadas pelo plano de saúde da empresa; e mudar a lógica da internação psiquiátrica para outros serviços substitutivos em saúde mental como, por exemplo, o Centro de Atenção Psicossocial 
Álcool e Drogas ${ }^{1}$ (CAPSAD) possibilitaria pensar a saúde mental dos trabalhadores para outros horizontes.

Em 2013, essa minha experiência profissional foi somada com a minha entrada no grupo de pesquisa Saúde Mental e Gênero coordenado pela professora Dra. Valeska Zanello, orientadora deste projeto na Universidade de Brasília. O objetivo do grupo é realizar uma leitura do campo da saúde mental sob um viés feminista das relações de gênero (e interseccionalidades com raça e etnia) no que diz respeito à epistemologia, semiologia, diagnóstico psiquiátrico e prática profissional. Os estudos de gênero apontam que o gênero é como uma janela para a saúde mental. De fato, foi uma janela que se abriu e se transformou de fato em categoria de análise permanente em meus atendimentos em psicologia e na pesquisa.

Nesse ínterim, com a "semente de gênero plantada" me candidatei para a seleção de mestrado desta universidade com o objetivo de pesquisar a depressão em homens. Por que quis estudar a depressão em homens? Em resumo, minha pergunta inicial de pesquisa era: "a depressão masculina vem por conta da perda de privilégios ou pela busca de caminhos alternativos, por protesto ao patriarcado"? Isto é, a motivação nasceu de perguntas sobre os afetos masculinos, por um lado impactada por algumas histórias e atendimentos com homens conforme mencionadas, e por outro lado fomentada por uma sede teórica, como também afetiva, e, clínica, em compreender os caminhos de subjetivação masculina.

O projeto de pesquisa seguiu adiante com minha aprovação no processo seletivo de mestrado. Exercia nessa empresa uma jornada de 40 horas semanais, o que não me possibilitaria cursar as disciplinas do mestrado, e por esta razão, entrei com o pedido de licença sem vencimento (para estudos). Por mais que a empresa tivesse as condições e

\footnotetext{
${ }^{1}$ O CAPSAD é uma unidade de saúde especializada em atender as pessoas que se encontram em situação de abuso e/ou dependência de álcool e drogas. Atende as diretrizes determinadas pelo Ministério da Saúde por meio da Política Nacional de Saúde Mental e da Lei Federal 10.216/2001 (lei antimanicomial).
} 
os recursos para convocação de mais uma psicóloga para minha substituição por meio de aprovação de concurso público, o pedido foi negado. Ter o pedido negado na época me chamou bastante atenção por vários motivos: por ser uma empresa de grande porte, por seu quadro majoritário masculino, e por este projeto apresentar possibilidades futuras de implementação de ações e programas em saúde mental para os trabalhadores. Fiquei com uma pergunta em mente por algum tempo: "De repente este estudo não os interesse... por quais motivos"? Conforme exposto, não tive o apoio institucional e optei por me desligar do órgão e me dedicar integralmente à pesquisa. Contei com o apoio financeiro da bolsa de estudo de pós-graduação concedida pelo Conselho Nacional de Desenvolvimento Científico e Tecnológico $(\mathrm{CNPq})$ já no terceiro mês de entrada no mestrado.

Em suma, as escolhas e a conseqüente tomada de decisões que envolveram a entrada, a permanência e a finalização do curso de mestrado passaram por momentos reflexivos e não deixaram de ter angústias ora construtivas ora bem desafiadoras. Foi uma elaboração afetiva e cognitiva, com percalços. Falar dela é de certo modo contar sobre o passado com as lentes do presente e trazer a possibilidade de ressignificação da caminhada.

Não foram apenas por esses dilemas que passei, como a falta de apoio daquela instituição, característica de muitas instituições públicas e privadas no Brasil (de não investimento e não incentivo a pesquisa). Neste percurso fui interpelada em muitos momentos pela condição de ser feminista e pesquisadora da área das masculinidades, em que me foi possível fazer uma espécie de "faxina pessoal" da "casa dos homens" na minha vida afetiva e laboral. Foram muitas reflexões, tais como acerca do que é

\footnotetext{
${ }^{2}$ Faço esta anedota em referência à categoria criada na pesquisa de Maurice Godelier sobre os Baruya na Nova Guiné (1966/1969) (Welzer-Lang, 2001). Esta categoria me inspira por abordar sobre os segredos, as iniciações e as violências perpetradas de formas hierárquicas entre os homens de diversas idades e posteriormente incorporadas na cultura local em relação aos homens e, sem dúvida, às mulheres.
} 
esperado e performado por um homem e por uma mulher nas mais diversas relações e situações sociais em uma cultura patriarcal. Igualmente, lembro-me de me questionar e também ser questionada por colegas de curso e amigas feministas: "os homens são machistas mesmo; os homens não mudam; não existe depressão em homem!!!; eles vão sofrer por quais motivos?; são eles que detêm os privilégios!!!”

Além disso, em muitos momentos, me vi entrando em uma espécie de silenciamento e esgotamento do campo de pesquisa: foi um campo de ambigüidades por ser uma pesquisadora mulher e ouvir histórias de sofrimentos de homens (lidas neste estudo pelo viés de gênero), do que foi possível eles me falarem por ser mulher e, sobretudo, do que foi possível ouvir das narrativas sabendo dos limites epistemológicos.

Por fim, outra dificuldade que não posso deixar de apontar diz respeito à escassez de literatura em psicologia sobre depressão com viés de gênero; e nesse sentido as orientações e as supervisões individuais e em grupo com colegas da pós-graduação, coordenado por minha orientadora, foram imprescindíveis. Nelas, discutimos horas a fio sobre as teorias, em sua maioria sobre os estudos feministas e os estudos culturais, bem como as pesquisas em gênero, sem deixar de nos implicarmos sobre nossos afetos por estudar tais temas, os quais, sem dúvida, não deixam de impactar também nossa saúde mental.

\section{Depressão e masculinidades}

A possibilidade de existência dos estudos das masculinidades surgiu com o advento dos movimentos feministas e das mulheres no final da década de 60 e no início dos anos 70. A categoria gênero (inicialmente englobando somente as mulheres) passou a ser uma categoria de análise relacional e política. Visou à igualdade das mulheres por direitos civis, políticos e educativos (primeira fase), introduziu a noção de equidade e 
paridade (segunda fase) e foram revisitadas algumas categorias de análise, tais como o conceito de gênero, a política identitária das mulheres, o conceito de patriarcado e as formas da produção do conhecimento científico (terceira fase) (Narvaz \& Koller, 2006).

Embora, desde a década de 60, transformações sociais tenham ocorrido, a distinção e a hierarquia de gênero se mantêm fortemente até os dias de hoje, ou seja, firma-se uma desigualdade entre mulheres e homens, justificada muitas vezes por "descobertas científicas" marcadas pela eleição da diferença anatômica e fisiológica específicas, as quais visam localizar nos corpos a distinção de subjetividades (Laquer, 2001).

A categoria gênero configura-se, assim, como uma ferramenta crítica/pertinente da cultura. As subjetividades são inscritas por marcadores locais, étnicos, gendrados e sociais, por exemplo, as masculinidades inseridas em contextos de privilégio e poder, interseccionadas entre nível local, regional e global em que homens brancos, ricos e americanos ou europeus estão no topo (Connell \& Messerschimidt, 2013) e por muitos casos de violência estrutural, em países colonizados em que mulheres de cor e pobres são as que mais sofrem (Farmer, 2002; Zanello \& Silva, 2012).

Os estudos das masculinidades iniciam-se com os movimentos sociais e estudos sobre as masculinidades gays nos anos 70 (Welzer-Lang, 2004). Já a saúde dos homens começou a ser estudada nos fins dessa década e a pesquisa sobre o processo saúde e doença masculina inicia-se nos anos 90 (Medrado, Lyra, \& Azevedo, 2011). Um processo social novo se instalou em movimentos e organizações não governamentais (ONGs) admitindo problemas na ordem patriarcal, e ao modelo predominante de masculinidade com a construção da violência (Pereira, 2014). No Brasil foi criada a Política Nacional de Atenção Integral à Saúde do Homem, em 2008. Esta política segue 
as diretrizes dos determinantes sociais de saúde do Sistema Único de Saúde (SUS) e objetiva, no plano geral, reduzir os índices de mortalidade masculina (Brasil, 2008).

Sem dúvida, dentro do debate feminista e dos estudos de gênero, o campo das masculinidades tem pontos divergentes. Algumas feministas apontam que no momento histórico em que as mulheres ainda estão na luta pela garantia de direitos, que reafirmar a oposição (feminino e masculino) é importante. Não apenas isso, há muito para realizar e problematizar sobre a situação das mulheres antes de ocupar-se com outras pessoas; ocupar-se dos homens seria uma perda de tempo, um esforço inútil (Moreno, 2016). Há igualmente a necessidade de questionar um otimismo perigoso caracterizado por movimentos masculinos que visam à manutenção e consolidação de sua dominação sobre as mulheres (Vigoya, 2007; Pereira, 2014).

Em outras palavras, em tempos de reatualizações do patriarcado, o campo de estudo da "depressão masculina" coloca-nos em uma tarefa tênue e desafiadora entre analisar as relações e a opressão de gênero, e entre compreender os caminhos de subjetivação e "adoecimento masculino" em uma cultura patriarcal. Isto é, o patriarcado violenta as mulheres, oprime-as ${ }^{3}$ e por ora também coloca os homens presos em uma matriz binária e hegemonicamente dominante. De fato, pesquisar sobre gênero não é uma tarefa fácil. As performances gendradas são sistematicamente repetitivas, cansativas, violentas e não deixam de trazer incômodos afetivos e de fomentos reflexivos.

\footnotetext{
${ }^{3}$ Neste sentido, gostaria de apontar dois casos que me marcaram muito como mulher que dizem da produção heteronormativa masculina. Duas notícias impactaram a cidade de Brasília e ao Brasil nestes últimos meses: uma estudante de biologia da Universidade de Brasília (UnB) foi assassinada, em março de 2016, por um ex-namorado, o motivo do feminicidio teria sido a recusa da jovem em ter um relacionamento com ele. Ademais, na cidade do Rio de Janeiro uma jovem de 16 anos foi estuprada por 33 homens no mês de maio, ou seja, em um país como o Brasil que está entre os países com maior índice de homicídios femininos: ocupa a quinta posição em um ranking de 83 nações, segundo dados do Mapa da Violência (Flacso, 2015), muito está se dizendo sobre a produção normativa da casa dos homens e das masculinidades brasileiras. Por mais que este estudo foque na "depressão" em homens, este imaginário coletivo reforça a violência contra as mulheres e a construção subjetiva das masculinidades marcadas pela virilidade sexual e pela violência.
} 
Outra reflexão necessária para o campo de estudos das masculinidades diz respeito de que se fala muito dos homens, do sistema de dominação que eles usam contra as mulheres, e mesmo de suas crises e dúvidas, contudo faltam estudos em uma problemática crítica da dominação masculina e estudos consistentes sobre a construção das masculinidades (Welzer-Lang, 2004; Figueroa-Perea, 2016).

Por outro lado, esta pesquisa tem o potencial de criação de um debate, pois possibilita ouvir os homens sobre seus afetos, e pode fomentar reflexões para os estudos das masculinidades e para o campo de saúde mental e da psicologia clínica, haja vista que o gênero é analisado como marcador importante na construção subjetiva das masculinidades. Portanto, levando em consideração como a masculinidade é construída e os processos de subjetivação a ela relacionadas, pergunta-se, neste estudo, acerca se há ou não e que tipo de sofrimento acontece aos homens que não se enquadram dentro de uma masculinidade hegemônica $^{4}$ e, nesse sentido, se há alguma relação, por exemplo, com os quadros de depressão.

Com esse propósito, a dissertação se construiu em dois capítulos em formato de artigo. O primeiro artigo intitulado Depressão e Masculinidades: uma revisão sistemática da literatura em periódicos brasileiros trata de um levantamento e uma revisão sistemática da literatura publicada acerca do tema "depressão masculina" nas bases científicas LILACS e SciELO Brasil de 2003 a 2013. Neste artigo, procedeu-se o levantamento e foi feita uma análise da literatura, levando em consideração os principais fatores associados à temática em questão e quais foram as categorias analíticas utilizadas. Quanto aos artigos analisados, a maior parte deles foi de caráter epidemiológico e comparativo com as mulheres e nesse sentido foram encontrados apenas dois estudos qualitativos. Por conseqüência da ausência de estudos qualitativos

\footnotetext{
${ }^{4}$ Categoria proveniente de estudos de campo sobre desigualdade social nas escolas australianas (Connell \& Messerschimidt, 2013). Esta categoria será utilizada nesta pesquisa e discutida no decorrer da dissertação.
} 
que escutem esse público, foi delineado o próximo artigo. No segundo artigo, intitulado Depressão em homens: uma leitura a partir das masculinidades foi realizada uma pesquisa qualitativa utilizando o método história de vida, em que foram escutados três homens diagnosticados com depressão em um hospital público. A partir da gravação e da transcrição das entrevistas, foram analisados os dados biográficos à luz das teorias das masculinidades.

A presente dissertação teve por objetivo estabelecer um diálogo entre a saúde mental, especificamente a depressão, e o campo de gênero, através do viés das masculinidades. 


\title{
ARTIGO 1- DEPRESSÃO E MASCULINIDADES: UMA REVISÃO SISTEMÁTICA DA LITERATURA EM PERIÓDICOS BRASILEIROS
}

\begin{abstract}
RESUMO
O presente trabalho teve como objetivo fazer um levantamento bibliográfico e uma revisão sistemática da literatura brasileira publicada acerca do tema "depressão masculina" entre os anos de 2003 e 2013, nas principais plataformas brasileiras LILACS e SciELO Brasil. Buscou-se não apenas mapear estes estudos, mas analisar se e como os estudos das masculinidades têm contribuído para este campo. Para tanto, foram utilizados oito descritores de gênero e nove de saúde mental/depressão. Foram encontrados na plataforma LILACS 1378 artigos e na base SciELO 386. Os trabalhos científicos que não trataram a depressão como foco principal foram descartados, assim como aqueles que estudavam a depressão como decorrente de doenças físicas. Apenas 17 artigos enquadraram-se nos critérios de inclusão. Dentre eles, 15 utilizaram a metodologia quantitativa, usando testes psicométricos, e 14 destes tiveram como objetivo fazer um levantamento epidemiológico comparativo com as mulheres. Entre os principais fatores associados à depressão apontados para todas as faixas etárias analisadas (jovens, adultos e velhos) estão baixa escolaridade, classe social, desemprego e estado civil (não ter uma companheira). De forma predominante, o fenômeno da depressão não foi analisado levando em consideração os estudos das masculinidades e de raça/etnia. Além disso, apenas duas pesquisas realizaram entrevistas com os homens, o que aponta a invisibilidade de pesquisas qualitativas e um incipiente número de pesquisas que os escutem. A contribuição do presente estudo é apontar justamente esta lacuna.
\end{abstract}

Palavras chave: Masculinidades; depressão; saúde mental. 


\begin{abstract}
The aim of this study was to search for and make a systematic review of the literature published on the issue "male depression" in the brazilian scientific databases LILACS and SciELO Brazil, from 2003 to 2013. It investigates whether and how the study of masculinities have contributed to this field. We used eight gender descriptors and nine mental health/depression descriptors. LILACS returned 1378 articles and SciELO 386. The articles that have not dealt with depression as the main focus were discarded, as well as those that studied depression as a result of physical illnesses. Only 17 articles have fulfilled the inclusion criteria. Fifteen of those used quantitative methodology including psychometric tests; and 14 of them aimed at comparing male and female epidemiological data. Among the main factors associated with depression reported at all age groups analyzed (youth, adults and older populations) are low level of education, social class, unemployment and marital status (not having a partner). Predominantly depression has not been analyzed taking into account the studies on masculinities and race/ethnicity. Besides, only two of the surveys conducted interviews with men pointing, therefore, the invisibility of qualitative research and pauper number of research that listen to men. The study contributes just to point this gap.
\end{abstract}

Keywords: Masculinities; depression; mental health. 


\section{RESUMEN}

El presente trabajo tuvo como objetivo hacer una investigación y una revisión sistemática de la literatura publicada acerca del tema "depresión masculina" en las plataformas científicas LILACS y SciELO Brasil, de 2003 a 2013. Se buscó no sólo para mapear estos estudios, analizar si y como el estudio de las masculinidades han contribuido a este campo. Para tanto, fueron utilizados ocho descriptores de género y nueve de salud mental/depresión. Fueron encontrados en la plataforma LILACS 1378 y en la base SciELO 386. Los estudios científicos no han tratado la depresión como el foco principal se descartaron, así como los que estudiaron la depresión como resultado de enfermedades físicas. Apenas 17' artículos se encuadran en los criterios de inclusión. Entre ellos, 15 utilizaron la metodología cuantitativa, incluyendo pruebas psicométricas y 14 de ellos tuvieron como objetivo hacer un levantamiento epidemiológico comparativo con las mujeres. Entre los principales factores asociados a la depresión señalados para todos los rangos etarios analizados (jóvenes, adultos y viejos) están la baja escolaridad, clase social, desempleo y estado civil (no tener pareja). De forma predominante, el fenómeno de la depresión no fue analizado llevando en consideración los estudios de las masculinidades y de la raza/etnia. Además de eso, apenas en dos investigaciones se realizaron entrevistas con hombres, lo que apunta a invisibilidad de investigaciones cualitativas y un incipiente número de investigaciones que los escuchen. La contribución de este trabajo es precisamente apuntar esta omisión.

Palabras clave: Masculinidades; depresión; salud mental. 


\section{INTRODUÇÃO}

Se a masculinidade se ensina e se constrói não há dúvida de que ela pode mudar. No século XVIII, um homem digno deste nome podia chorar em público e ter vertigens; no final do século XIX, não o pode mais, sob pena de comprometer sua dignidade masculina. O que constitui pode, portanto, ser demolido para ser novamente construído (Badinter, 1993, p. 23).

Dados da Organização Mundial de Saúde (OMS) apontam que, em média, 1 (uma) em cada 20 pessoas relatou ter um episódio de depressão no ano anterior, bem como afeta aproximadamente 350 milhões de pessoas; sendo que há perda de quase 1 milhão de vidas decorrente do suicídio, o que se traduz em 3.000 mortes todos os dias (Who, 2012).

Na maioria dos países, a depressão varia de $8 \%$ a $12 \%$. As diferentes culturas e os diferentes fatores de risco parecem afetar a expressão da depressão, porém alguns deles são comuns. Aspectos como pobreza, baixa escolaridade, familiares com depressão, exposição à violência, estar separado ou divorciado, especialmente no caso dos homens, e outras doenças crônicas, estão altamente correlacionados com a depressão. Além disso, destaca-se uma diferença epidemiológica importante: a depressão ocorre, em média, duas a três vezes mais em mulheres do que em homens (Who, 2012).

Segundo Zanello (2014), faz-se necessário que os dados epidemiológicos sejam tomados como dados construídos, e não como fatos. Para tanto, deve-se levar em consideração, antes do levantamento estatístico, a descrição sindrômica do que se chama atualmente de "Depressão". 
Autores, tais como Shear, Halmi, Widiger e Boyce (2007), Phillips e First (2008), Widiger e First (2008) e Zanello (2014), têm apontado o gendramento da descrição desse quadro clínico. Para Lutz (1985), o estado emocional de tristeza é visto como uma das características definidoras do estado patológico de depressão, se não o mais central. Zanello (2014) sublinha, neste sentido, a presença de "choro", dado como exemplo do sintoma de tristeza em um dos principais manuais de classificação dos transtornos mentais (DSM- Manual Diagnóstico e Estatístico de Transtornos Mentais). Porém sua expressão é mediada pelos valores de gênero. Na cultura ocidental, os homens são subjetivados em um ideal hegemônico de virilidade, no qual se deve suprimir a expressão afetiva de fragilidade, o que os leva a raramente chorar em público ou na frente de outra pessoa (Zanello, 2014).

A ausência deste sintoma poderia levar à não percepção da tristeza em muitos homens e, conseqüentemente, ao não diagnóstico de depressão dentre eles. Zanello (2014) aponta assim a falibilidade de se fiar em dados epidemiológicos na área de saúde mental, sem criticar sua base epistemológica, sobretudo pelo viés de gênero. Neste sentido, a falta de questionamento poderia levar a um hiperdiagnóstico de depressão entre mulheres e a um subdiagnóstico no caso dos homens.

Levando em consideração essa perspectiva, autores tais como Phillips e First (2008) e Widiger e First (2008) propõem soluções para a manutenção dos grandes manuais de classificação diagnóstica a partir de levantamento feito da literatura sobre este debate. De um lado, há quem sugira que haja uma descrição de sinais e sintomas de certas síndromes de forma diferenciada para homens e mulheres; por outro lado, há quem discorde da necessidade desta descrição diferenciada e aponte que a diferença deveria ocorrer no número de sintomas necessários para perfazer a síndrome, caso seja 
um homem ou uma mulher. Apesar da existência destas críticas, realizadas, sobretudo, ao DSM IV, não houve mudanças significativas nestes quesitos no DSM V.

A construção cultural da(s) masculinidade(s) parece, portanto, afetar a expressão do sofrimento por parte dos homens. De acordo com Welzer-Lang (2001), as masculinidades são configurações de práticas sociais e culturais que passam por aprendizados, atos, códigos, performances e ritos. O aprendizado de ser homem começa na infância, nos espaços sociais, clube, escola e principalmente entre os seus pares. Segundo o autor, os códigos viram rito e, depois, operadores hierárquicos. Em nossa cultura, essa aprendizagem se faz no sofrimento, na dor de ter que competir, ser melhor, endurecer o corpo, não expressar fragilidade. O mimetismo dos homens seria um mimetismo de violências: (1) violência inicialmente contra si mesmo; (2) violência guerra contra os outros. Em suma: são construções que passam por ideais de uma virilidade fabricada, sempre no imperativo - dever de ser homem e no negativo - de não se assemelhar às mulheres (Badinter, 1993; Welzer-Lang, 2001).

Por consequência desses marcadores, se dá uma aprendizagem viril que se constrói no paradigma homofóbico. Ou seja, a discriminação contra as pessoas que mostram, ou apresentam algumas características atribuídas ao outro gênero. Isto garante aos "grandes homens" privilégios à custa das mulheres (como todos os homens), mas também à custa dos próprios homens - "próprios pares”. Nesse duplo poder estruturamse as hierarquias masculinas (Welzer-Lang, 2001).

A ideia de uma hierarquia das masculinidades cresceu diretamente a partir da violência sofrida por homens homossexuais e do preconceito dos homens heterossexuais. Apenas, talvez, uma minoria dos homens adote a masculinidade hegemônica. Porém, ela não deixa de ser normativa. Há um descompasso entre a essencialização do conceito e a tremenda multiplicidade das construções sociais que 
etnógrafos/as e historiadores/as têm documentado com o auxílio desse conceito. A característica fundamental desta categoria continua a ser a combinação da pluralidade e a hierarquia entre as masculinidades, sendo a ideal/hegemônica a branca e heterossexual (Connell \& Messerschmidt, 2013; Pereira, 2014).

Diante do exposto, questiona-se como a configuração cultural das masculinidades, na cultura ocidental, comparece e contribui para a configuração e expressão dos transtornos mentais, especificamente da depressão em homens. Trata-se de uma questão relevante.

A saúde dos homens começou a ser estudada nos fins da década de 70 e o processo saúde e doença masculina nos anos 90 (Medrado, Lyra \& Azevedo, 2011). Apesar dos avanços na área da saúde (geral) do homem, os estudos sobre sua saúde mental são ainda bastante incipientes.

Levando em consideração a contribuição que os estudos das masculinidades podem aportar para o campo de saúde mental, especificamente para a compreensão da depressão em homens, o presente estudo buscou realizar um levantamento bibliográfico e uma revisão sistemática da literatura brasileira publicada entre os anos de 2003 e 2013 sobre o tema "depressão masculina", nas principais plataformas brasileiras LILACS e SciELO Brasil.

\section{METODOLOGIA}

Neste artigo, foi realizado um levantamento bibliográfico e uma revisão sistemática da literatura sobre o tema "depressão em homens", em duas grandes plataformas científicas brasileiras LILACS (Base de dados da Literatura LatinoAmericana e do Caribe em Ciências da Saúde) e SciELO Brasil (Biblioteca eletrônica que integra periódicos científicos do Brasil, da América Latina e do Caribe). 
A revisão sistemática consiste em fazer um levantamento de estudos já publicados sobre um tema específico com o intuito de buscar respostas a determinadas questões, o que exige a definição de um problema de pesquisa, uma estratégia de busca de estudos, estabelecimento de critérios de inclusão e exclusão dos artigos, a fim de que seja feita uma análise criteriosa acerca da qualidade da literatura selecionada (Costa \& Zoltowski, 2014; Petticrew \& Roberts, 2006).

Estas plataformas científicas foram escolhidas por agregarem grande parte dos periódicos brasileiros qualificados. LILACS é um índice bibliográfico da literatura relativa às ciências da saúde a partir de 1982 (congrega aproximadamente 1500 periódicos, indexados e não indexados). Já a plataforma SciELO é uma biblioteca eletrônica que abrange uma coleção de periódicos científicos e disponibiliza, gratuitamente, os textos completos de artigos de inúmeras revistas científicas. Dentro das suas ferramentas de busca, é possível selecionar uma pesquisa restrita ao SciELO Brasil, que está vinculada somente a periódicos brasileiros. A pesquisa foi realizada nessa plataforma, visto que o objetivo deste trabalho era fazer um levantamento das produções brasileiras acerca do tema.

O período recortado foi o intervalo entre os anos 2003 a 2013. A busca foi realizada nos meses de agosto e setembro de 2014. Já a análise foi realizada de agosto de 2014 a agosto de 2015. O levantamento foi dividido em 06 (seis) etapas: a) levantamento numérico de publicações e exclusão dos repetidos; b) levantamento dos resumos dos artigos; c) classificação por tema; d) leitura do artigo; e) categorização; f) análise. O processo foi realizado por duas pessoas. Não houve conflito de interesses.

Foram utilizados dois grupos de descritores. O primeiro relacionado a homem com oito descritores: homem; homens; gênero; masculinidade; masculinidades; virilidade; masculina; masculino. O segundo relacionado à depressão com nove 
descritores: depressão; quadro depressivo; transtorno depressivo; transtorno depressivo maior; transtorno de humor; loucura; sofrimento mental; sofrimento psíquico; saúde mental, totalizando 72 combinações.

Para a pesquisa nas plataformas, os descritores foram utilizados com operadores booleanos (AND), bem como o truncamento (asterisco) para as variações da palavra. Foram encontradas inicialmente na base LILACS e SciELO Brasil, respectivamente, 1378 e 386 artigos.

Todos os resumos foram lidos e analisados. Foram retirados os repetidos. Os critérios de inclusão foram os seguintes: a) tratar da depressão seja como fenômeno sociocultural, doença, síndrome, transtorno e/ou por um conjunto de sintomas; b) ter homens, ou homens e mulheres como sujeitos da pesquisa; c) pesquisas referentes ao público brasileiro, realizadas sob qualquer filiação institucional nacional ou global; d) desconsideradas as dissertações e as teses; e) foram levadas em consideração todas as faixas etárias, exceto menores de 16 anos.

Importante destacar que nem sempre esses dados ficavam evidentes no resumo. Nesses casos, os artigos foram incluídos para análise minuciosa posterior. Aplicados os critérios de inclusão, restaram, nas bases LILACS e SciELO Brasil, 60 e 80 artigos respectivamente. Esses artigos foram lidos na íntegra e submetidos a uma análise a partir da seguinte classificação: foco (depressão como assunto central), fundo (depressão dentro de um conjunto de "transtornos" e/ou "patologias"), primária (depressão não decorrente de doenças físicas) e secundária (depressão decorrente de alguma alteração de cunho biomédico, intervenção cirúrgica e/ou outras intercorrências).

Após a leitura minuciosa de todos os artigos, mais 45 foram descartados (das duas plataformas) por diversos motivos, tais como: tratarem de depressão bipolar; não 
tratarem efetivamente da depressão; pesquisas anteriores a 2003 ou posteriores a 2013; e por fim não tratarem do público masculino.

Finalmente, restaram em cada grupo o seguinte: foco primário (10 artigos no LILACS e 7 no SciELO Brasil); foco secundário (4 artigos no LILACS e 15 no SciELO Brasil); fundo primário (9 artigos no LILACS e 27 no SciELO Brasil); fundo secundário (5 artigos no LILACS e 18 no SciELO Brasil) (conforme Figura 1 no anexo).

Após a classificação nas duas bases científicas, foram selecionados somente os 17 artigos que tratavam da depressão como foco total (depressão como assunto central e excluídos os artigos que levavam em consideração outras psicopatologias) e primário (depressão não decorrente de doenças físicas).

Estes artigos foram minuciosamente analisados no que diz respeito aos seguintes fatores: como surgiu o tema (pesquisa por demanda institucional e/ou motivações de pesquisa); ano de publicação; campo teórico-metodológico do/a pesquisador/a; sexo do/a pesquisador/a; faixa etária do público masculino estudado; sexo dos sujeitos de pesquisa (se apenas homens ou homens e mulheres); presença ou não de teoria explícita e implícita de depressão; presença/ausência de teorias de gênero e masculinidades; e por fim, raça/etnia.

\section{RESULTADOS E DISCUSSÃO}

Dos 17 artigos, $16^{5}$ tinham como foco uma comparação entre homens e mulheres, apenas 1 (um) teve como foco exclusivamente os homens (Botti et al., 2010). Houve uma predominância de estudos sobre a prevalência de depressão.

\footnotetext{
5 (Avanci, Assis \& Oliveira, 2008; Batistoni, Neri \& Cupertino, 2010; Borges, Benedetti, Xavier \& D'Orsi (2013); César et al., 2013; Coelho et al., 2013; Cunha, Bastos, \& Duca, 2012; Damião, Coutinho, Carolino \& Ribeiro, 2011; Ferreira \& Tavares, 2013; Gonçalves \& Andrade, 2010; Justo \& Calil, 2006;
} 
Dos 17 artigos analisados, 15 tratavam da incidência de sintomas ou da própria depressão como síndrome/transtorno. Para o diagnóstico foram utilizados diversos instrumentos. Entre eles, as seguintes escalas, questionários, testes e manuais diagnósticos: Escala de Depressão de Yesavage - dois artigos (Gonçalves \& Andrade, 2010; Siqueira et al., 2009); Escala de Depressão do Centro de Estudos epidemiológicos - Center for Epidemiologic Studies Depression Scale - um artigo (Coelho et al., 2013); Escala de Depressão Geriátrica Breve - um artigo (Oliveira et al., 2012); Escala de Depressão Pós-Natal de Edimburgo - um artigo (Cunha et al., 2012); Escala Patient Healht Questionnaire - dois artigos (Zinn-Souza et al., 2008; César et al., 2013); Geriatric Depression Scale - um artigo (Lima et al., 2009); Escala de Cornell um artigo (César et al., 2013); Inventário de Beck - dois artigos (Botti et al., 2010; Rocha et al., 2006); Escala Center for Epidemiological Studies - Depression - um artigo (Batistoni et al., 2010); Mini Exame do Estado Mental - MEEM - um artigo (Ferreira \& Tavares, 2013); Self-Reported - SRQ-20 - um artigo (Avanci et al., 2008); Questionário "Brasil Old Age Schedule” - BOAS - um artigo (Leite et al., 2006); Questionário BOMFAQ - rastreamento da depressão - um artigo (Borges et al., 2013). Estes foram os principais instrumentos utilizados na própria detecção da depressão, ou seja, na seleção do público estudado, ainda que houvesse, em algumas pesquisas, outros instrumentos de avaliação mais qualitativos.

Três estudos (Zinn-Souza et al., 2008; Avanci et al., 2008; Rocha et al., 2006) tiveram como foco levantar a prevalência da depressão entre adolescentes e encontraram as seguintes incidências: $7,5 \%, 10 \%$ e 45,7\%, A maior foi entre as meninas em todos os estudos. Nas pesquisas cujo foco foi os/as idosos/as (em 9 
$\operatorname{artigos}^{6}$ ), a incidência foi maior entre as mulheres (em 8 artigos, variando entre 14,2\%, chegando até 58\%). E na única pesquisa que tratou do público adulto (Botti et al., 2010) a prevalência foi de $56,3 \%$. E, por fim, nos estudos realizados com todas as faixas etárias - em 3 artigos (Botti et al., 2010; Coelho et al., 2013; Cunha et al., 2012), exceto adolescentes, ou seja, com adultos/as e idosos/as, a prevalência foi de 16,1\%, 28,7\% e $56,3 \%$ e foi maior nos dois estudos que compararam homens e mulheres.

Das 15 pesquisas de prevalência, somente em 2 (duas) houve a realização de entrevistas (Batistoni et al., 2010; Coelho et al., 2013). No entanto, foram utilizadas nas entrevistas questionários e escalas diagnósticas. Ou seja, a fala do sujeito não apareceu como importante, sendo o objetivo das entrevistas apenas a confirmação da presença ou não de sintomas depressivos já previamente estabelecidos nos manuais, caracterizandose por uma lógica binária, típica do fazer psiquiátrico (Zanello, Macedo \& Romero, 2012). Neste sentido, a pesquisa de Batistoni et al. (2010) menciona que foram realizadas entrevistas com os/as idosos/as, mas não apontam o que eles/as disseram, somente destacando em suas falas a manifestação de sintomas depressivos.

Na pesquisa de Coelho et al. (2013), do mesmo modo que a de Batistoni et al. (2010), embora 3007 pessoas tenham sido entrevistadas, é apenas reportado o tempo de duração da entrevista, mas não há referência aos relatos dessas pessoas e quais foram de fato as suas contribuições para o estudo, o que nos leva a concluir que não houve análise qualitativa deste material. A ênfase recaiu sobre o material estatístico e descritivo de sintomas depressivos confirmados por testes e escalas diagnósticas.

Destaca-se a quase inexistência de pesquisas qualitativas, bem como a preponderância de estudos comparativos de ocorrência da depressão entre homens e mulheres, por meio de uso de testes psicológicos e da classificação pelos manuais

\footnotetext{
${ }^{6}$ (Batistoni et al., 2010; Borges et al., 2013; César et al., 2013; Ferreira \& Tavares, 2013; Gonçalves \& Andrade, 2010; Leite et al., 2006; Lima et al., 2009; Oliveira et al., 2012; Siqueira et al., 2009).
} 
diagnósticos (DSM- Manual Diagnóstico e Estatístico de Transtornos Mentais e o CIDClassificação Internacional de Doenças). Para compreender o sofrimento psíquico, que é mediado pela cultura, é necessário escutar o que essas pessoas têm a dizer (Maluf \& Tornquist, 2010; Zanello, 2014).

Apenas 2 (dois) artigos não realizaram estudo de prevalência. O estudo de Justo e Calil (2006) teve por objetivo apontar diferenças na depressão entre homens e mulheres com base na revisão de literatura. A prevalência predominante no sexo feminino foi justificada, de um lado, por especificidades genéticas e hormonais e, por outro, por aspectos psicossociais, tais como maior vulnerabilidade em função da sobrecarga nas tarefas domésticas; abuso sexual na infância, dentre outros fatores. Não houve questionamento sobre os critérios que poderiam subdiagnosticar casos de depressão em homens, por exemplo.

Na outra pesquisa, segundo Damião et al. (2011), o objetivo foi de identificar os fatores psicossociais que interferem na etiologia da depressão e apreender as Representações Sociais acerca da depressão dentre adolescentes. Tratou-se de um estudo descritivo exploratório, de caráter qualitativo e quantitativo. Participaram do estudo 505 sujeitos, entre os quais 269 eram da cidade de Teresina e 236 de Natal. De forma geral, os adolescentes apresentaram traços depressivos mais relacionados a problemas de conduta e obediência, enquanto as adolescentes desenvolveram traços mais subjetivos, que foram lidos pelos/as autores/as como sentimentos de tristeza.

Com base no CDI (Children's Depression Inventory), que constitui uma adaptação do BDI (Inventário de Depressão de Beck), na cidade de Natal dos 236 sujeitos (misto: escola pública e privada), 5\% apresentaram indicativo de sintomatologia depressiva; e em Teresina o índice foi de 11,1\%. Entre todos os fatores pesquisados no $\mathrm{CDI}$, foram os sujeitos do sexo feminino que obtiveram as maiores médias. Entre estes 
fatores, podemos citar sentimentos de tristeza, ideação suicida e choro. Essa prevalência foi explicada à luz do funcionamento neuro-hormonal feminino. Isto é, mesmo quando os sujeitos são ouvidos, a explicação continua a recair sobre causas biologizantes, sem analisar aspectos sociais de gênero e raça. Além disso, os/as pesquisadores/as utilizaram de forma acrítica os sistemas diagnósticos.

Grande parte das 17 pesquisas foi publicada na região Sudeste (10), seguida pela região Nordeste (5) e, por último, pela região Sul (2). Treze das 17 pesquisas foram publicadas entre 2008 e 2013. Isso pode ter acontecido devido à implementação da Política Nacional de Saúde Integral do Homem em 2008 (Brasil, 2008) (conforme Tabela 1 no anexo).

No que diz respeito ao sexo dos sujeitos pesquisados destaca-se que somente 1 (uma) pesquisa (Botti et al., 2010) tratou especificamente dos homens, as demais foram mistas, comparando homens e mulheres. A prevalência de depressão foi de $56,3 \%$ em homens que vivem em situação de rua na cidade de Belo Horizonte. A maior frequência da depressão grave se deu com jovens adultos e de depressão leve, moderada e grave entre os homens que se encontram entre um e seis meses morando na rua.

Quanto ao sexo dos/as pesquisadores/as, todas as pesquisas foram de co-autoria, variando de 2 (dois) a 7-8 (sete-oito) co-autores/as, mistos (homens e mulheres). O campo teórico/metodológico dos/as pesquisadores/as foi variado: educação física, enfermagem, fisioterapia, medicina, psiquiatria, saúde coletiva, saúde pública, terapia ocupacional. Ressalta-se que somente 1 (uma) pesquisa foi realizada por pesquisadores/as psicólogos/as (Rocha et al., 2006), apesar de a psicologia ter um papel importante dentro da reforma psiquiátrica e das discussões em saúde mental no Brasil.

A grande maioria dos artigos científicos não explicita como se chegou ao tema de pesquisa "depressão masculina". Supõe-se que a maior parte tenha surgido de 
pesquisa universitária. As demandas governamentais que apareceram foram as seguintes: Projeto EPIDOSO da Unifesp (Lima et al., 2009); Projeto Tecnologias assistidas para idosos atendidos em Unidades de Saúde da Família (Oliveira et al., 2012); Inquérito EpiFloripa Idoso (Borges et al., 2013); Demanda da Secretaria Nacional Antidrogas - SENAD (Coelho et al., 2013).

De modo prevalente, 9 (nove) pesquisas tratavam somente da velhice; 4 (quatro) de adolescentes, 3 (três) de todas as faixas etárias (exceto crianças) e 1 (uma) apenas com adultos homens. E, por fim, não foi encontrada nenhuma pesquisa com crianças (dentro do recorte metodológico que abarca somente depressão primária). Destaca-se que somente a pesquisa de Botti et al. (2010) tratou do público masculino adulto, mesmo com a implantação da Política Nacional de Atenção Integral a Saúde do Homem em 2008, cujo foco principal é a população de homens adultos, na faixa de 20 a 59 anos.

Conforme apontado anteriormente, a maioria das demandas públicas que originaram os estudos referiam-se à velhice e, não coincidentemente, essa foi a fase da vida mais enfocada nos estudos encontrados. Este pode ser um possível sintoma, gendrado, em nossa cultura, no qual ser velho e estar fora do "mercado" laboral e sexual (ideais hegemônicos de masculinidade) pode criar quebra psíquica e rupturas (Zanello, Silva \& Henderson, 2015).

Nenhum dos artigos levou em consideração os estudos de gênero em geral e, muito menos, remeteu-se aos estudos das masculinidades. Mesmo os/as autores/as que compararam os sexos ou aspectos sociais relacionados aos sexos não se utilizaram destes estudos, embora este campo epistemológico tenha se expandido e fortalecido desde a década de 60/70. Além disso, somente duas pesquisas (Gonçalves \& Andrade, 2010; Borges et al., 2013) levaram em consideração os aspectos raciais/étnicos, apesar de que existam estudos que apontam ser a identidade racial e o racismo um fator de 
sofrimento e risco para a saúde mental (Fanon, 2008; Amantino \& Freire, 2013; Pinho, 2014; Zanello \& Gouveia, no prelo).

A pesquisa de Gonçalves e Andrade (2010) retrata a prevalência de depressão, afetando homens negros e sedentários, com agravamento conforme avanço da idade e influenciando na piora da qualidade de vida. Dos/as 16 negros/as ${ }^{7}$ estudados, 15 apresentaram sintomas depressivos (93,8\%). Já dos 22 mulatos/as, em 11 (onze) foram encontrados sintomas depressivos (50\%). E dos 64 brancos/as, 25 foram identificados sintomas depressivos (39,1\%). Na pesquisa de Borges et al. (2013), os/as autores/as identificaram a raça, porém não realizaram a análise racial, pois, segundo os/as autores/as, o teste estatístico não revelou diferença significativa entre quantidade de manifestações depressivas.

Foram apontados os seguintes fatores associados à depressão em homens, levando em consideração todas as faixas etárias analisadas: pertencer às classes sociais mais baixas (Borges et al., 2013; Justo \& Calil, 2006; Oliveira et al., 2012); apresentar baixa escolaridade (Batistoni et al., 2010; Borges, et al., 2013; César et. al., 2013; Cunha et al., 2012; Justo \& Calil, 2006; Leite et al., 2006; Oliveira et al., 2012); estar na linha da extrema pobreza (Botti et al., 2010); estar desempregado (Botti et al., 2010); consumir substâncias psicoativas (Avanci et al., 2008; Zinn-Souza et al., 2008); estar solteiro, separado, divorciado ou viúvo (Borges et al., 2013; Cunha et al., 2012; Gonçalves \& Andrade, 2010; Justo \& Calil, 2006; Leite et al., 2006; Oliveira et al., 2012; Lima et al., 2009); ser jovem e trabalhador de classes mais baixas (Zinn-Souza et al., 2008); viver na região Norte do Brasil (Coelho et al., 2013); viver em zona rural (Ferreira \& Tavares, 2013); ser negro (Gonçalves \& Andrade, 2010).

\footnotetext{
${ }^{7}$ Esta identificação de raça/etnia foi feita pelos/as pesquisadores/as em tela.
} 
Ao falar de saúde mental masculina nos estudos de prevalência é importante ressaltar que os fatores correlacionados à depressão referem-se aos homens como também às mulheres, uma vez que somente um estudo focou-se no público masculino, ou seja, nos demais não houve análise específica para cada sexo.

No que tange à ocorrência de depressão na adolescência, os estudos indicaram os seguintes fatores associados: insatisfação com a vida; violências físicas e sexuais cometidas contra o adolescente pelos/as cuidadores/as - no caso em questão - mãe e pai (Avanci et al., 2008); quanto mais velho for o adolescente maior a chance de sentir- se deprimido devido ao insucesso escolar por conta do exame do vestibular (Rocha et al., 2006); consumo pessoal de substâncias psicoativas (Avanci et al., 2008; Zinn-Souza et al., 2008); trabalhar e estudar ao mesmo tempo no caso de alunos/as da pesquisa realizada em escola pública (Zinn-Souza et al., 2008).

Já na velhice, os estudos assinalaram a alta prevalência de depressão, sendo este o "transtorno" mais comum nessa fase da vida devido prioritariamente à comorbidade e à incapacidade funcional (Batistoni et al., 2010; Borges et al., 2013; Ferreira \& Tavares, 2013; Leite et al., 2006; Oliveira et al., 2012; Siqueira et al., 2009) aumentando a partir dos 70 anos (Gonçalves \& Andrade, 2010; Leite et al., 2006; Lima et al., 2009; Oliveira et al., 2012).

Mesmo que fatores associados à depressão tenham sido ressaltados para cada fase de vida, não se questionou como e porque tais fatores constituem-se em vulnerabilidades para os homens. Conforme aponta Welzer-Lang (2001), as masculinidades passam por aprendizados, atos, códigos, performances e ritos. Neste sentido, a aprendizagem de "tornar-se homem" por meios performáticos, marcados pela masculinidade hegemônica, pode diferir entre um adolescente, um adulto e um idoso. A velhice, por exemplo, pode ser vivida pela perda de traços identitários, marcada pelo 
luto de uma virilidade sexual e laborativa exercida na juventude e na vida adulta (Zanello et al., 2015). Já na adolescência, o fracasso escolar coloca em questão a cobrança de ser eficiente e produtivo e, portanto, a possibilidade de sucesso de uma certa performance hegemônica do ser "homem". Em suma, é necessário que haja mais pesquisas qualitativas onde se crie espaço para se ouvir estas pessoas, suas histórias de vida, pois tais pesquisas, em que a idade ou a fase da vida é um marcador importante, poderiam identificar configurações culturais significativas na construção das masculinidades, bem como dos fatores que as colocam em xeque.

\section{CONSIDERAÇÕES FINAIS}

O objetivo deste artigo foi fazer um levantamento da produção bibliográfica brasileira publicada entre os anos de 2003 a 2013 nas duas principais plataformas científicas brasileiras, LILACS e SciELO Brasil, sobre o tema da depressão masculina, levando em consideração a contribuição que os estudos das masculinidades podem apontar para o campo da saúde mental.

Quatorze dos dezessete artigos encontrados tiveram como foco a comparação epidemiológica da ocorrência de depressão entre homens e mulheres por meio de testagem e somente em dois estudos as pessoas foram escutadas por intermédio de entrevistas. A maioria dos artigos tratou da população idosa: onze dos dezessete artigos abordaram os/as velhos/as, em que nove deles focaram somente nessa população e dois deles incluíram todas as faixas etárias, exceto crianças. Por fim, nenhum se utilizou das teorias de gênero e das masculinidades para a análise teórica e metodológica.

Como apontado, os sintomas descritos nos manuais de classificação diagnóstica têm sido questionados por seu enviesamento de gênero. $\mathrm{O}$ exemplo mais claro, neste caso, seria a detecção da tristeza pelo choro, a qual ocorre com mais frequência em 
mulheres. Isto coloca em evidência a necessidade de questionarmos a variabilidade de suas expressões, mediadas em nossa cultura, pelos valores e ideais de gênero. Como foi visto, pela imposição de uma masculinidade hegemônica, garantida pela violência entre os pares, a maior parte dos homens desaprende cedo a chorar na frente de outras pessoas, ou a demonstrar qualquer fragilidade. Isto já levantaria a questão sobre quais seriam as formações sintomáticas privilegiadas nos casos de depressão masculina e se elas são contempladas nas listas dos manuais de classificação diagnóstica.

Os fatores correlacionados nos artigos com os casos de depressão masculina sugerem a participação dos valores e ideais de masculinidade, tais como: estar solteiro, separado, divorciado ou viúvo; classe social e idade. Possivelmente há razões gendradas que levam a maioria dos homens que estão solteiros, separados, viúvos ou divorciados, bem como com a idade avançada na velhice (em que há maior perda laboral e sexual) e de classe social mais baixa, a apresentarem sintomas depressivos.

Antes de finalizar, faz-se necessário apontar dois limites da presente pesquisa: o primeiro deles trata-se da existência de artigos sobre o tema que podem não ter aparecido nestas plataformas por terem sido publicados em revistas a elas não indexadas; e, o segundo limite se deve à possibilidade do uso de outros descritores que não foram considerados neste estudo. Assim, apesar de o levantamento ter utilizado 72 combinações possíveis de descritores, pode ocorrer que algum artigo tenha escapado, pelo fato de o/a autor/a ter escolhido outros descritores.

Sugere-se, a partir dos artigos encontrados, que para compreender o sentido das correlações da depressão com fatores associados, faz-se necessário que se realize mais pesquisas qualitativas, com a criação de um espaço de escuta clínica, na qual sejam considerados os aspectos subjetivos das masculinidades e suas diferentes interpelações nas diferentes fases da vida dos homens. 


\section{REFERÊNCIAS ${ }^{8}$}

Amantino, M. \& Freire, J. (2013). História dos homens no Brasil. In M. D. Priore; M. Amantino (Org.), Ser homem... Ser escravo (pp.15-48). São Paulo: Unesp.

* Avanci, J. Q., Assis, S. G., \& Oliveira, R. V. C. (2008). Sintomas depressivos na adolescência: estudo sobre fatores psicossociais em amostra de escolares de um município do Rio de Janeiro, Brasil. Cadernos de Saúde Pública, 24(10), 23342346. doi: http://www.scielo.br/pdf/csp/v24n10/14.pdf

Badinter, E (1993). XY. Sobre a identidade masculina. (Trad. M. I. D. Estrada). Rio de Janeiro: Nova Fronteira (Original publicado em 1992).

* Batistoni, S. S. T., Neri, A. L., \& Cupertino, A. P. F. B. (2010). Medidas prospectivas de sintomas depressivos entre idosos residentes na comunidade. Revista de Saúde Pública, 44(6), 1137-1143. doi: http://www.scielo.br/pdf/rsp/v44n6/1467.pdf

* Borges, L. J., Benedetti, T. R. B., Xavier, A. J., D’Orsi, E. (2013). Fatores associados aos sintomas depressivos em idosos: estudo EpiFloripa. Revista de Saúde Pública, 47(4), 701-710. doi: http://www.scielo.br/pdf/rsp/v47n4/0034-8910-rsp-47-040701.pdf

* Botti, N. C. L., Castro, C. G. de, Silva, M. F. da, Silva, A. K., Oliveira, L. C. de, Castro, A. C. H. O. A. D. et al. (2010). Prevalência de depressão entre homens adultos em situação de rua em Belo Horizonte. Jornal Brasileiro de Psiquiatria, 59(1), 10-16. doi: http://www.scielo.br/pdf/jbpsiq/v59n1/v59n1a02

Brasil, Ministério da Saúde (2008). Política nacional de atenção integral à saúde do homem. Princípios e Diretrizes. Brasília: Ministério da Saúde. Recuperado em 01 de abril, 2015, de http://bvsms.saude.gov.br/bvs/publicacoes/politica nacional atencao saude home $\underline{\text { m.pdf }}$

* César, K. G., Takada, L. T., Brucki, S. M. D., Nitrini, R., Nascimento, L. F. C., Oliveira, M. O, et al. (2013). Prevalence of depressive symptoms among elderly in the city of Tremembé, Brazil: preliminary findings of an epidemiological study. Neuropsychol, 7(3). doi: http://www.redalyc.org/articulo.oa?id=339529044004

* Coelho, C. L. S., Crippa, J. A. S., Santos, J. L. F, Pinsky, I., Zaleski, M., Caetano, R. et al. (2013). Higher prevalence of major depressive symptoms in Brazilians aged

\footnotetext{
${ }^{8}$ As referências com asterisco na frente referem-se aos artigos levantados e analisados na revisão sistemática.
} 
14 and older. Revista Brasileira de Psiquiatria, 35(2), 142-149. doi: http://www.scielo.br/pdf/rbp/v35n2/1516-4446-rbp-2013-35-2-142.pdf

Connell, R. W., \& Messerschmidt, J. W. (2013). Masculinidade hegemônica: repensando o conceito. Estudos Feministas, Florianópolis, 21 (1), 241-282. doi: http://www.scielo.br/pdf/ref/v21n1/14.pdf

Costa, A. B., \& Zoltowski, A. P. C. (2014). Como escrever um artigo de revisão sistemática. In S. H. Koller, M. C. P. de Paula, \& J. V. C. Hohendorff (Orgs.), Manual de Produção Científica (pp.55-70). Porto Alegre: Penso.

* Cunha, R. V. D, Bastos, G. A. N., \& Duca, G. F. D. (2012). Prevalência de depressão e fatores associados em comunidade de baixa renda de Porto Alegre. Revista Brasileira de Epidemiologia, 15(2), 346-354. doi: http://www.scielo.br/pdf/rbepid/v15n2/12.pdf

* Damião, N. F. Coutinho, M. P. L, Carolino, Z. C. G. \& Ribeiro, K. C. S. (2011). Representações sociais da depressão no ensino médio: um estudo sobre duas capitais. Psicologia \& Sociedade; 23 (1): 114-124. doi: http://www.scielo.br/pdf/psoc/v23n1/a13v23n1.pdf

Fanon, F. (2008). Pele negra, máscaras brancas. Salvador: EDUFBA.

* Ferreira, P. C. dos S., \& Tavares, D. M. dos S. (2013). Prevalência e fatores associados ao indicativo de depressão entre idosos residentes na zona rural. Revista Da Escola de Enfermagem da USP, 47(2), 401-407. doi: http://www.scielo.br/pdf/reeusp/v47n2/18.pdf

* Gonçalves, V. C., \& Andrade, K. L. (2010). Prevalência de depressão em idosos atendidos em ambulatório de geriatria da região nordeste do Brasil (São Luís-MA). Revista Brasileira de Geriatria e Gerontologia, 13(2), 289-300. doi: http://www.scielo.br/pdf/rbgg/v13n2/a13v13n2.pdf

* Justo, L. P., \& Calil, H. M. (2006). Depressão: o mesmo acometimento para homens e mulheres? Revista de Psiquiatria Clínica, 33(2), 74-79. doi: http://www.scielo.br/pdf/rpc/v33n2/a07v33n2.pdf

* Leite, V. M. M., Carvalho, E. M. F. D, Barreto, K. M. L., \& Falcão, I. V. (2006). Depressão e envelhecimento: estudo nos participantes do Programa Universidade Aberta à Terceira Idade. Revista Brasileira de Saúde Materno Infantil, 6(1), 31-38. doi: http://www.scielo.br/pdf/rbsmi/v6n1/a04v6n1.pdf 
* Lima, M. T. da R., Silva, R. de S., \& Ramos, L. R. (2009). Fatores associados à sintomatologia depressiva numa coorte urbana de idosos. Jornal Brasileiro de Psiquiatria, 58(1), 1-7. doi: http://www.scielo.br/pdf/jbpsiq/v58n1/a01v58n1.pdf

Lutz, C. (1985). Depression and the translation of emotional worlds. In A. Kleinman, B. Good (Orgs.), Culture and Depression Studies in the Antropology and Crosscultural Psychiatry of Affect and Disorder (pp. 63-100). Berkeley Los Angeles London: University of California Press.

Maluf, S. W., \& Tornquist, C. S (2010). Gênero, saúde e aflição: abordagens antropológicas. Florianópolis: Letras Contemporâneas.

Medrado, B., Lyra, J., \& Azevedo, M. (2011). Saúde do homem em debate. In R. Gomes (Org.), 'Eu Não Sou Só Próstata, Eu Sou um Homem!' Por uma política pública de saúde transformadora da ordem de gênero (pp.39-75). Rio de Janeiro: Fiocruz.

* Oliveira, M. F. D., Bezerra, V. P., Silva, A. O., Alves, M. D. S. C. F., Moreira, M. A. S. P., \& Caldas, C. P. (2012). Sintomatologia de depressão autorreferida por idosos que vivem em comunidade. Ciência \& Saúde Coletiva, 17(8), 2191-2198. doi: http://www.scielo.br/pdf/csc/v17n8/29.pdf

Pereira, F. P. (2014). "Seja Homem": Produção de masculinidades em contexto patriarcal. Curitiba, PR: CRV.

Petticrew, M., \& Roberts, H. (2006). Systematic review in the social science: A pratical guide. Malden, MA: Blackwell Publishing.

Phillips, K. A. \& First, M. B. (2008). Gênero e Idade - considerações no diagnóstico psiquiátrico: agenda de pesquisa para DSM-V. In W. E. Narrow. et al (Org.), Capítulo 1 Introdução (pp. 3-5). São Paulo: Roca.

Pinho, O. (2014). Um enigma masculino: Interrogando a masculinidade da desigualdade racial no Brasil. Universitas. Humanística. 77, 227-250. doi: http://www.scielo.org.co/pdf/unih/n77/n77a10.pdf

* Rocha, T. H. R., Ribeiro, J. E. C., Pereira, G. D. A., Aveiro, C. C., \& Silva, L. C. D. A.-M. (2006). Sintomas depressivos em adolescentes de um colégio particular. 
Psico-USF,

$11(1)$

95-102.

doi:

http://www.redalyc.org/articulo.oa?id=401036065011

Shear, K., Halmi, K. A., Widiger, T. A., \& Boyce, C. (2007). Age and gender considerations in psychiatric diagnosis: A research agenda for DSM-V. In W.E. Narrow. et al (Org.), Sociocultural factors and gender (pp. 65-79). Washington: American Psychiatric Association.

* Siqueira, G. R. D., Vasconcelos, D. T. D, Duarte, G. C., Arruda, I. C. D., Costa, J. A. S. D., \& Cardoso, R. D. O. (2009). Análise da sintomatologia depressiva nos moradores do Abrigo Cristo Redentor através da Escala de Depressão Geriátrica (EDG). Ciência \& Saúde Coletiva, 14(1), 253-259. doi: http://www.scielo.br/pdf/csc/v14n1/a31v14n1.pdf

Welzer-Lang, D (2001). A construção do masculino: dominação das mulheres e homofobia. Revista Estudos Feministas, Florianópolis, 9 (2), 460-482. doi: http://www.scielo.br/pdf/ref/v9n2/8635.pdf

Widiger, T. A. \& First, M. B. (2008). Gênero e Idade - considerações no diagnóstico psiquiátrico: agenda de pesquisa para DSM-V. In W. E. Narrow. et al (Org.), Gênero e Critérios Diagnósticos (pp. 124-134). São Paulo: Roca.

World Health Organization - WHO (2012). Depression: A Global Crisis World Mental. Health Day. Occoquan: USA. Recuperado em 20 de outubro, 2014, de http://www.who.int/mental health/management/depression/wfmh paper_depressio n wmhd 2012.pdf

Zanello, V., Macedo, G., \& Romero, A. C. (2012). Entrevistas de evolução psiquiátricas: entre a doença mental e a medicalização. Mental, 17, 621-640, 2012. doi: http://pepsic.bvsalud.org/pdf/mental/v9n17/08.pdf

Zanello, V. (2014). A saúde mental sob o viés de gênero: uma releitura gendrada da epidemiologia, da semiologia e da interpretação diagnóstica In V. Zanello; A. P. M. D. Andrade (Orgs.), Saúde Mental e Gênero. Diálogos, Práticas e Interdisciplinaridade (pp. 41-58). Curitiba: Editora Appris.

Zanello, V., Silva, L.C., \& Henderson, G. (2015) Saúde Mental, Gênero e Velhice na Instituição Geriátrica. Psicologia, Teoria e Pesquisa, 31 (4). doi: http://www.scielo.br/pdf/ptp/v31n4/1806-3446-ptp-31-04-00543.pdf

Zanello, V.; Gouveia, M. (no prelo). Psicopatologia e racismo. 
* Zinn-Souza, L.C., Nagai, R., Teixeira, L. R., Latorre, M.R.D.O., Roberts, R., Cooper, S. P. et al. (2008). Factors associated with depression symptoms in high school students in São Paulo, Revista de Saúde Pública, Brazil, 42(1), 34-40. doi: http://www.scielo.br/pdf/rsp/v42n1/6345.pdf 
ANEXO 1

\begin{tabular}{|c|c|c|c|c|c|c|c|}
\hline AUTORES/AS & $\begin{array}{l}\text { TÍTULO DO } \\
\text { ARTIGO } \\
\end{array}$ & $\begin{array}{l}\text { BASE } \\
\text { CIENTÍFICA } \\
\end{array}$ & $\begin{array}{l}\text { FASE DA } \\
\text { VIDA } \\
\end{array}$ & MÉTODO & $\begin{array}{l}\text { PREVALÊNCIA } \\
\text { (SIM/NÃO) }\end{array}$ & $\begin{array}{l}\text { INSTRUMENTO } \\
\text { DIAGNÓSTICO } \\
\end{array}$ & $\begin{array}{l}\text { CAMPO TEÓRICO } \\
\text { PESQUISADOR/A }\end{array}$ \\
\hline $\begin{array}{l}\text { Siqueira et al. } \\
(2009)\end{array}$ & $\begin{array}{l}\text { Análise da } \\
\text { sintomatologia } \\
\text { depressiva nos } \\
\text { moradores do } \\
\text { Abrigo Cristo } \\
\text { Redentor através } \\
\text { da Escala de } \\
\text { Depressão } \\
\text { Geriátrica (EDG) }\end{array}$ & $\begin{array}{l}\text { SciELO } \\
\text { Brasil }\end{array}$ & Idosos/as & Quantitativa & Sim & $\begin{array}{l}\text { Escala de } \\
\text { Depressão de } \\
\text { Yesavage }\end{array}$ & Fisioterapia \\
\hline $\begin{array}{l}\text { Leite et al. } \\
(2006)\end{array}$ & $\begin{array}{l}\text { Depressão e } \\
\text { envelhecimento: } \\
\text { estudo nos } \\
\text { participantes do } \\
\text { Programa } \\
\text { Universidade } \\
\text { Aberta à Terceira } \\
\text { Idade }\end{array}$ & $\begin{array}{l}\text { SciELO } \\
\text { Brasil }\end{array}$ & Idosos/as & Quantitativa & Sim & $\begin{array}{l}\text { Questionário } \\
\text { "Brasil Old } \\
\text { Age Schedule" } \\
\text { - BOAS }\end{array}$ & $\begin{array}{l}\text { Terapia } \\
\text { Ocupacional e } \\
\text { Saúde coletiva }\end{array}$ \\
\hline $\begin{array}{l}\text { Justo \& Calil } \\
(2006)\end{array}$ & $\begin{array}{l}\text { Depressão - o } \\
\text { mesmo } \\
\text { acometimento } \\
\text { para homens e } \\
\text { mulheres? }\end{array}$ & $\begin{array}{l}\text { SciELO } \\
\text { Brasil }\end{array}$ & Adultos & $\begin{array}{l}\text { Revisão } \\
\text { Narrativa da } \\
\text { Literatura }\end{array}$ & Não & & Psiquiatria \\
\hline $\begin{array}{l}\text { Zinn-Souza et } \\
\text { al. (2008) }\end{array}$ & $\begin{array}{l}\text { Factors associated } \\
\text { with depression } \\
\text { symptoms in high } \\
\text { school students in } \\
\text { São Paulo, Brazil }\end{array}$ & LILACS & Adolescentes & Quantitativa & Sim & $\begin{array}{l}\text { Escala Patient } \\
\text { Healht } \\
\text { Questionnaire }\end{array}$ & $\begin{array}{l}\text { Saúde pública e } \\
\text { Saúde ambiental }\end{array}$ \\
\hline $\begin{array}{l}\text { Lima et al. } \\
(2009)\end{array}$ & $\begin{array}{l}\text { Fatores associados } \\
\text { à sintomatologia } \\
\text { depressiva numa } \\
\text { coorte urbana de } \\
\text { idosos }\end{array}$ & LILACS & Idosos/as & Quantitativa & Sim & $\begin{array}{l}\text { Geriatric } \\
\text { Depression } \\
\text { Scale }\end{array}$ & Medicina \\
\hline $\begin{array}{l}\text { Borges et al. } \\
(2013)\end{array}$ & $\begin{array}{l}\text { Fatores associados } \\
\text { aos sintomas } \\
\text { depressivos em } \\
\text { idosos: estudo } \\
\text { EpiFloripa }\end{array}$ & LILACS & Idosos/as & Quantitativa & Sim & $\begin{array}{l}\text { Questionário } \\
\text { BOMFAQ - } \\
\text { rastreamento } \\
\text { da depressão }\end{array}$ & $\begin{array}{l}\text { Educação Física } \\
\text { e Saúde Coletiva }\end{array}$ \\
\hline $\begin{array}{l}\text { Coelho et al. } \\
(2013)\end{array}$ & $\begin{array}{l}\text { Higher prevalence } \\
\text { of major } \\
\text { depressive } \\
\text { symptoms in } \\
\text { Brazilians aged } 14 \\
\text { and older }\end{array}$ & LILACS & $\begin{array}{l}\text { Adolescentes, } \\
\text { adultos e } \\
\text { idosos/as }\end{array}$ & Quantitativa & Sim & $\begin{array}{l}\text { Escala de } \\
\text { Depressão do } \\
\text { Centro de } \\
\text { Estudos } \\
\text { epidemiológico } \\
s\end{array}$ & $\begin{array}{l}\text { Psiquiatria, } \\
\text { Neurociência, } \\
\text { Medicina Social }\end{array}$ \\
\hline $\begin{array}{l}\text { Batistoni et al. } \\
\text { (2010) }\end{array}$ & $\begin{array}{l}\text { Medidas } \\
\text { prospectivas de } \\
\text { sintomas } \\
\text { depressivos entre } \\
\text { idosos residentes } \\
\text { na comunidade }\end{array}$ & $\begin{array}{l}\text { SciELO } \\
\text { Brasil }\end{array}$ & Idosos/as & Quantitativa & Sim & $\begin{array}{l}\text { Escala Center } \\
\text { for } \\
\text { Epidemiologic } \\
\text { al Studies - } \\
\text { Depression }\end{array}$ & Humanas \\
\hline
\end{tabular}




\begin{tabular}{|c|c|c|c|c|c|c|c|}
\hline AUTORES/AS & $\begin{array}{l}\text { TÍTULO DO } \\
\text { ARTIGO } \\
\end{array}$ & $\begin{array}{l}\text { BASE } \\
\text { CIENTÍFICA }\end{array}$ & $\begin{array}{l}\text { FASE DA } \\
\text { VIDA } \\
\end{array}$ & MÉTODO & $\begin{array}{l}\text { PREVALÊNCIA } \\
\text { (SIM/NÃO) }\end{array}$ & $\begin{array}{l}\text { INSTRUMENTO } \\
\text { DIAGNÓSTI- } \\
\text { COS }\end{array}$ & $\begin{array}{l}\text { CAMPO TEÓRICO } \\
\text { PESQUISADOR/A }\end{array}$ \\
\hline $\begin{array}{l}\text { Cunha et al. } \\
(2012)\end{array}$ & $\begin{array}{l}\text { Prevalência de } \\
\text { depressão e } \\
\text { fatores associados } \\
\text { em comunidade } \\
\text { de baixa renda de } \\
\text { Porto Alegre, Rio } \\
\text { Grande do Sul }\end{array}$ & LILACS & $\begin{array}{l}\text { Adultos e } \\
\text { idosos/as }\end{array}$ & Quantitativa & Sim & $\begin{array}{l}\text { Escala de } \\
\text { Depressão } \\
\text { Pós-Natal de } \\
\text { Edimburgo }\end{array}$ & $\begin{array}{l}\text { Saúde coletiva e } \\
\text { da Família }\end{array}$ \\
\hline $\begin{array}{l}\text { Gonçalves \& } \\
\text { Andrade } \\
(2010) \\
\end{array}$ & $\begin{array}{l}\text { Prevalência de } \\
\text { depressão em } \\
\text { idosos atendidos } \\
\text { em ambulatório de } \\
\text { geriatria da região } \\
\text { nordeste do Brasil }\end{array}$ & LILACS & Idosos/as & Quantitativa & Sim & $\begin{array}{l}\text { Escala de } \\
\text { Depressão de } \\
\text { Yesavage }\end{array}$ & Medicina \\
\hline $\begin{array}{l}\text { Botti et al. } \\
(2010)\end{array}$ & $\begin{array}{l}\text { Prevalência de } \\
\text { depressão entre } \\
\text { homens adultos } \\
\text { em situação de rua } \\
\text { em Belo } \\
\text { Horizonte }\end{array}$ & $\begin{array}{l}\text { SciELO } \\
\text { Brasil }\end{array}$ & $\begin{array}{l}\text { Adultos } \\
\text { (somente em } \\
\text { homens) }\end{array}$ & Quantitativa & Sim & $\begin{array}{l}\text { Inventário de } \\
\text { Beck }\end{array}$ & Enfermagem \\
\hline $\begin{array}{l}\text { Ferreira \& } \\
\text { Tavares (2013) }\end{array}$ & $\begin{array}{l}\text { Prevalência e } \\
\text { fatores associados } \\
\text { ao indicativo de } \\
\text { depressão entre } \\
\text { idosos residentes } \\
\text { na zona rural }\end{array}$ & LILACS & Idosos/as & Quantitativa & Sim & $\begin{array}{l}\text { Mini Exame do } \\
\text { Estado Mental } \\
\text { - MEEM }\end{array}$ & Enfermagem \\
\hline $\begin{array}{l}\text { Rocha et al. } \\
(2006)\end{array}$ & $\begin{array}{l}\text { Sintomas } \\
\text { depressivos em } \\
\text { adolescentes de } \\
\text { um colégio } \\
\text { particular }\end{array}$ & $\begin{array}{l}\text { SciELO } \\
\text { Brasil }\end{array}$ & Adolescentes & Quantitativa & Sim & $\begin{array}{l}\text { Inventário de } \\
\text { Beck }\end{array}$ & $\begin{array}{l}\text { Psicologia, } \\
\text { Estatística e } \\
\text { Medicina }\end{array}$ \\
\hline $\begin{array}{l}\text { Avanci et al. } \\
(2008)\end{array}$ & $\begin{array}{l}\text { Sintomas } \\
\text { depressivos na } \\
\text { adolescência: } \\
\text { estudo sobre } \\
\text { fatores } \\
\text { psicossociais em } \\
\text { amostra de } \\
\text { escolares de um } \\
\text { município do Rio } \\
\text { de Janeiro, Brasil } \\
\end{array}$ & LILACS & Adolescentes & Quantitativa & Sim & $\begin{array}{l}\text { Self-Reported - } \\
\text { SRQ } 20\end{array}$ & Saúde pública \\
\hline $\begin{array}{l}\text { Oliveira et al. } \\
(2012)\end{array}$ & $\begin{array}{l}\text { Sintomatologia de } \\
\text { depressão } \\
\text { autorreferida por } \\
\text { idosos que vivem } \\
\text { em comunidade }\end{array}$ & $\begin{array}{l}\text { SciELO } \\
\text { Brasil }\end{array}$ & Idosos/as & Quantitativa & Sim & $\begin{array}{l}\text { Escala de } \\
\text { Depressão } \\
\text { Geriátrica } \\
\text { Breve }\end{array}$ & $\begin{array}{l}\text { Enfermagem e } \\
\text { Saúde Coletiva }\end{array}$ \\
\hline $\begin{array}{l}\text { César et al. } \\
(2013)\end{array}$ & $\begin{array}{l}\text { Prevalence of } \\
\text { depressive } \\
\text { symptoms among } \\
\text { elderly in the city } \\
\text { of Tremembé, } \\
\text { Brazil }\end{array}$ & LILACS & Idosos/as & Quantitativa & Sim & $\begin{array}{l}\text { Escalas de } \\
\text { Cornell; } \\
\text { Questionário } \\
\text { Patient Health } \\
\text { Questionnaire }\end{array}$ & Medicina \\
\hline $\begin{array}{l}\text { Damião et al. } \\
(2011)\end{array}$ & $\begin{array}{l}\text { Representações } \\
\text { sociais da } \\
\text { depressão no } \\
\text { ensino médio: um } \\
\text { estudo sobre duas } \\
\text { capitais }\end{array}$ & LILACS & Adolescentes & Qualitativa & Não & & Psicologia \\
\hline
\end{tabular}

Tabela 1. Classificação dos artigos sobre depressão (17) analisados por fase da vida, método e campo teórico em periódicos indexados no LILACS e SciELO Brasil. 
ANEXO 2

\begin{tabular}{|c|c|}
\hline $\begin{array}{l}\text { Primeira Etapa: levantamento } \\
\text { numérico, excluídos os artigos } \\
\text { repetidos (1378 da base LILACS e } \\
386 \text { da base SciELO Brasil). }\end{array}$ & $\begin{array}{c}\text { Segunda Etapa: leitura dos } \\
\text { resumos (1378 artigos da base } \\
\text { LILACS e } 386 \text { da base SciELO } \\
\text { Brasil). }\end{array}$ \\
\hline $\begin{array}{l}\text { Quarta etapa: leitura na íntegra de } \\
140 \text { artigos (60 da base LILACS e } \\
80 \text { da base SciELO Brasil) em que } \\
\text { foram descartados mais } 45 \text { artigos } \\
\text { (que não atenderam os critérios de } \\
\text { inclusão) totalizando } 95 \text { artigos. }\end{array}$ & $\begin{array}{l}\text { Terceira Etapa: atendidos os } \\
\text { critérios de inclusão (restaram } 140 \\
\text { artigos: } 60 \text { da base LILACS e } 80 \text { da } \\
\text { base ScIELO Brasil) foi realizada } \\
\text { uma classificação temática. }\end{array}$ \\
\hline $\begin{array}{l}\text { Quinta Etapa: Dos } 95 \text { artigos foi } \\
\text { realizada uma categorização (foco, } \\
\text { fundo, primário e secundário). }\end{array}$ & $\begin{array}{l}\text { Sexta etapa: Foi realizada uma } \\
\text { análise dos } 17 \text { artigos com } \\
\text { depressão foco primário (10 da base } \\
\text { LILACS e } 7 \text { da base SciELO } \\
\text { Brasil). }\end{array}$ \\
\hline
\end{tabular}

Figura 1. Passos utilizados no método de seleção de artigos da revisão sistemática realizada. 


\title{
ARTIGO 2- DEPRESSÃO EM HOMENS: UMA LEITURA A PARTIR DAS MASCULINIDADES
}

\begin{abstract}
RESUMO
Segundo dados da Organização Mundial de Saúde (2012), a depressão em mulheres é de duas a três vezes mais comum do que nos homens. Trata-se de um fenômeno gendrado em nossa cultura. Levando em consideração leituras da saúde mental sob o prisma de gênero, os caminhos de subjetivação e de adoecimento psíquico em mulheres e homens seriam diferenciados. Como as masculinidades participam na configuração do quadro depressivo? Com o propósito de responder a esta pergunta, foi realizado um estudo qualitativo, utilizando o método histórias de vida, com três homens diagnosticados com depressão (sem comorbidades) em um hospital público em uma capital brasileira. Nos três casos analisados, as queixas se deram, sobretudo, pela incapacidade de firmar-se pela potência viril (laborativa e sexual), marcador importante apontado pelos estudos das masculinidades. Além do mais, há especificidades na configuração desse sofrimento a depender da faixa etária do sujeito, bem como das interseccionalidades de classe e raça.
\end{abstract}

Palavras-chave: Masculinidades. Depressão. Histórias de Vida. 


\begin{abstract}
According to the World Health Organization (2012), depression in women is two to three times more common than in men. It is a gendered phenomenon in our culture. Taking into account views of mental health from a gender perspective, the ways to subjectivation and to psychological distress in women and men would differentiate. How do masculinities contribute to the structure of a depression framework? Aiming to answer this question, a qualitative study was conducted using the life story method, with three men diagnosed with depression (with no comorbidities) in a public hospital in a capital city of Brazil. The three cases presented complaints mainly originated from the inability to stand up to the virile power in both working and sexual domains, an important marker identified by studies of masculinities. Furthermore, there are specificities in the configuration of this suffering depending on the age of the subject, as well as on the class and race intersectionalities.
\end{abstract}

Keywords: Masculinities. Depression. Life stories. 


\section{RESUMEN}

Según datos de la organización mundial de la salud (2012), la depresión en mujeres es de dos a tres veces más común que en hombres. Se trata de un fenómeno engendrado en nuestra cultura. Llevando en consideración lecturas de la salud mental sobre el prisma del género, los caminos de subjetivación y de padecimiento psíquico en mujeres y hombres serían diferenciados. ¿Cómo las masculinidades participan en la configuración del cuadro depresivo? con el propósito de responder a esta pregunta, fue realizado un estudio cualitativo, utilizando el método historias de vida, con tres hombres diagnosticados con depresión (sin comorbilidades) en un hospital público en una capital brasileña. En los tres casos analizados, las quejas, se dieron, principalmente, por la incapacidad de firmarse por la potencia viril (de trabajo productivo y sexual), marcador importante señalado por los estudios de las masculinidades. Además de esto, hay especificidades en la configuración de este sufrimiento a depender del rango etario del sujeto, bien como de las interseccionalidades de clase y raza.

Palabras clave: Masculinidades. Depresión. Historias de vida. 


\section{INTRODUÇÃO}

É sem dúvida a pequena quantidade de grupos e movimentos anti-sexistas entre os homens que explica a carência atual de pesquisadores que investigam essa questão (masculinidades). E entre os homens que estudam o masculino, como entre suas colegas feministas, podemos estabelecer ligações entre reflexões do movimento social e desconstruções científicas (Welzer-Lang, 2004, p.116).

Dados da Organização Mundial de Saúde (OMS) apontam que, em média, cerca de 1 (uma) em cada 20 pessoas relatou ter um episódio de depressão no ano anterior, e não apenas isso: ela ocorre, em média, duas a três vezes mais em mulheres do que em homens (Who, 2012). Porém, várias críticas têm sido feitas a este tipo de levantamento, pois pouco se reflete acerca do próprio gendramento dos sintomas descritos nos manuais psiquiátricos, utilizados justamente para detectar os casos (Phillips \& First, 2008; Widiger \& First, 2008; Zanello, 2014; Zanello, 2016). O cruzamento entre os estudos de saúde mental e de gênero são também por ora incipientes (Maluf, 2010; Müller, 2010; Zanello, 2014), e mais raros ainda os referentes à saúde mental dos homens.

Se a epidemiologia da depressão é um fenômeno gendrado e sociocultural, pouco se pesquisa sobre a depressão masculina e suas possíveis especificidades. E subitamente, quando há pesquisas sobre depressão em homens, poucas são qualitativas, portanto, raramente os homens são ouvidos, conforme levantamento bibliográfico e revisão sistemática realizada em duas das principais plataformas científicas brasileiras (Windmöller \& Zanello, no prelo). Além disso, por mais que muitos estudos falem dos 
homens e do sistema de dominação masculina, esses não os contextualizam em uma problemática de gênero consistente e sistemática sobre as masculinidades (Connell, 2005; Figueroa-Perea, 2016; Welzer-Lang, 2004).

Com o advento da luta pela emancipação das mulheres, houve uma contestação histórica da legitimidade do poder patriarcal. Os movimentos feministas abalaram a ideia de uma masculinidade natural reproduzida ao idêntico e de forma unívoca. Foram abertos caminhos de contestação àqueles homens que se sentiam incomodados em seus projetos identitários ${ }^{9}$. Isso transcorreu paralelamente a outros movimentos nos anos 70 , como no caso dos grupos de homens anti-sexistas, dos movimentos gays e estudos sobre as homossexualidades masculinas (Connell, 2005; Welzer-Lang, 2004).

Os estudos das masculinidades podem trazer aportes importantes para a leitura do campo da saúde mental dos homens. Para tanto, algumas categorias e dispositivos podem nos ajudar nesta tarefa, elencadas a seguir: as relações entre hegemonia, subordinação, cumplicidade e marginalização, bem como a categoria "masculinidade hegemônica" (Connell, 2005); duplo paradigma das masculinidades - homofobia e violência contra os próprios pares (homens) e as mulheres (Welzer-Lang, 2001; 2004); imperativo e negativo (Badinter, 1993) e, por fim, o dispositivo da eficácia (Zanello, 2016).

As categorias "hegemonia", "subordinação", "cumplicidade" e "marginalização" são analisadas no contexto de práticas e estruturas sociais. O conceito de "hegemonia", derivado das análises de Gramsci nas relações de classe, cria inteligibilidade à categoria "masculinidade hegemônica" ${ }^{10}$. Essa categoria incorpora a resposta aceita para o

\footnotetext{
${ }^{9}$ Contudo, o interesse dos homens em participar dos "estudos das mulheres", antes do desenvolvimento do conceito de gênero, nos anos 60 , foi vetado pelas mulheres, o que pelo menos no primeiro momento dado a experiência das mulheres com a dominação masculina foi necessário, as quais estamos de acordo segundo a análise de Giffin (2005).

${ }^{10}$ Na obra de Connell \& Messerschimidt (2013), os autores falam da categoria masculinidade hegemônica como proveniente de estudos de campo sobre desigualdade social nas escolas australianas (Kessler et al,
} 
problema da legitimidade do patriarcado e garante (ou tenta garantir) a posição dominante dos homens e a subordinação das mulheres (Connell, 2005).

A categoria "subordinação" estaria ligada às identidades gays. Entre os grupos de homens hetero e homo, os homens heterossexuais são dominantes e hegemônicos e os homens homossexuais são estigmatizados e subordinados pela experiência cotidiana, violência urbana, discriminação e boicotes pessoais, entre outros ${ }^{11}$. No que diz respeito à "cumplicidade", os homens estabelecem uma conexão com o projeto hegemônico, mesmo que não atinjam e corporifiquem a masculinidade hegemônica em termos materiais e simbólicos, porém, eles se tornam aliados entre si e muitas vezes não contestam o dividendo do patriarcado (autoridade e dominação por parte de outros homens). Por último a categoria "marginalização" refere-se às relações pelas quais passam as masculinidades de classes dominadas/subordinadas de raça/etnias que estariam fora do projeto hegemônico ${ }^{12}$. Vale ressaltar, em suma, que estas categorias não são pensadas como algo fixo, mas configurações de práticas gendradas e localizadas geograficamente nas esferas global, regional e local (Connell, 2005).

Segundo Welzer-Lang (2001), os meninos aprendem desde cedo a serem diferentes de uma menina e isso acaba por defini-los "sexualmente" e identitariamente, ou seja, a construção da identidade masculina passa pelo caminho da diferença binária. E neste aprendizado, engendra-se uma dupla violência: a violência inicialmente contra si mesmo, através do endurecimento do corpo e dos afetos; e a violência contra os outros homens, os quais sempre colocam em xeque a masculinidade uns dos outros.

1982), em uma discussão conceitual relacionada à construção das masculinidades, à experiência dos corpos dos homens (Raewyn Connell, 1983) e um debate sobre o papel dos homens na política sindical australiana (Connell, 1982).

${ }^{11}$ Connell contextualiza esta categoria na sociedade européia e americana contemporânea. Porém, aqui neste estudo, cabe incorporar esta categoria da subordinação às masculinidades latinas e certamente um exemplo notório seria a cultura homofóbica brasileira.

${ }^{12}$ Novamente, estendemos esta categoria ao nosso estudo. No caso do Brasil, os marginalizados decerto seriam os homens negros e/ou outras etnias, bem como os pobres, ou seja, àqueles que estão sujeitos a violência estrutural de nosso país frente ao pós-colonialismo, em que o hegemônico seria o homem branco e rico (Amantino \& Freire, 2013; Fanon, 2008; Farmer, 2002; Pinho, 2014). 
Para este autor, a masculinidade se constrói a partir da subjugação das mulheres e de outros pares-homens.

Partindo de estudos psicanalíticos e dos estudos de gênero, a historiadora Badinter (1993) aponta que a masculinidade se constrói em dois momentos: um imperativo da virilidade, ou seja, projeto imposto e repetido pelo patriarcado: "Seja homem"; "Prove que é homem"; "O "verdadeiro" homem é o homem viril"; e um negativo, ou seja, tudo o que o homem não pode ser: não pode ser dócil, dependente ou submisso $^{13}$, não pode ter relações sexuais nem relações muito íntimas com outros homens e nem ser impotente sexual com as mulheres.

Zanello (2016), a partir de seus estudos sob esta perspectiva, saúde mental e gênero, aponta a existência de diferentes caminhos privilegiados de subjetivação em nossa cultura (lida hegemonicamente) para homens e mulheres. Segundo a autora, os homens se subjetivam no dispositivo da eficácia, o qual se baseia em dois fatores: virilidade sexual e laborativa.

Assim, em nossa cultura, um "verdadeiro" homem deve ser provedor e "comedor". Tanto o desempenho sexual como a performance no trabalho (cuja chancela de sucesso são o dinheiro e o status) seriam aspectos identitários para os homens, diferentemente das mulheres cujos dispositivos são o amoroso e o materno (Zanello, 2016). As pesquisas realizadas em saúde mental sob esta perspectiva (Zanello \& Bukowitz, 2011; Zanello, Silva \& Henderson, 2015; Zanello, Fiuza, \& Costa, 2015a) apontam que, no adoecimento psíquico, são estas as duas principais fontes de sofrimento para os homens. De um lado, trata-se dos aspectos de vulnerabilidade pelos quais os homens são interpelados; por outro lado, com o adoecimento psíquico, trata-se

\footnotetext{
${ }^{13}$ Lido, aqui, em nossa sociedade como homossexual ou parecido com mulheres referente à dominação masculina.
} 
dos conteúdos mais presentes em suas queixas, marcadas, sobretudo, pela impotência e ineficácia.

Levando em consideração a necessidade de realização de pesquisas qualitativas na área da saúde mental com homens, especificamente sobre depressão, o presente estudo teve como objetivo escutar homens diagnosticados com "depressão" e compreender, sob a perspectiva dos estudos das masculinidades, os fatores envolvidos em seu adoecimento psíquico.

Apesar de várias críticas feitas à psicopatologização e à psiquiatrização (Canguilhem, 2009; Foucault, 1979/2009; Hernaez, 2000; Lutz, 1985; Szasz, 1976), esta pesquisa, por ora, não teve o objetivo de questionar o diagnóstico "depressão". Dessa forma a terminologia, oriunda da psicopatologia clássica, foi mantida por diferentes razões: pela utilização predominante dos/as profissionais de saúde que fazem uso dos seus sistemas diagnósticos correlatos (dentro do sistema biomédico tradicional); e para dialogar com esses saberes por meio de análises de outras fontes de conhecimento, tais como os estudos de gênero e das masculinidades.

\section{METODOLOGIA}

Foi realizado um estudo qualitativo, usando histórias de vida. A história de vida pesquisa o sentido da experiência narrada por seus atores. Segundo Minayo (2014), as narrativas nunca serão uma "verdade" sobre os fatos vividos, e sim, referem-se aos sentidos atribuídos pelos sujeitos. Este recontar pode também ser seletivo no sentido do informante omitir ou acrescentar fatos de acordo com a relação estabelecida com o/a pesquisador/a (Víctora, Knauth \& Hassen, 2000). A história de vida é sempre uma reconstrução baseada na percepção e avaliação atual do próprio sujeito (Minayo, 2014; Víctora, Knauth \& Hassen, 2000). 
Este método permite descrever um caso particular e, ao mesmo tempo, ilustrar de maneira concreta a estrutura social, ou seja, abre espaço para a interpretação sociológica e histórica. Sobretudo, a reconstrução histórica permite acessar experiências não documentadas sob a análise de categorias sociais geralmente menosprezadas e permite colocar os/as investigadores/as em relacionamentos humanos ativos na observação dos fatos e, por fim, permite enfatizar uma determinada etapa ou setor da vida (Minayo, 2014). Estes princípios condizem com os objetivos da pesquisa que focou a análise nos momentos de vida em que o sujeito vivenciou sentimentos depressivos e atende ao propósito de analisar histórias particulares sob a perspectiva de categorias sociais pouco utilizadas, ou seja, analisar histórias de homens diagnosticados com depressão sob a prerrogativa dos estudos das masculinidades e de saúde mental, evidenciada na psicologia clínica como um campo de estudo, de pesquisa e de intervenção incipiente conforme mencionado anteriormente.

O recrutamento ocorreu com o encaminhamento dos pacientes pelos profissionais que trabalham nas dependências de um hospital público em uma capital brasileira. Foram entrevistados todos os pacientes deste serviço que apresentaram o diagnóstico de depressão (sem comorbidades) entre os meses de outubro de 2015 a fevereiro de 2016 (tempo do campo) que corresponderam ao total de três homens. A quantidade de homens com diagnóstico de depressão foi bem abaixo do esperado e da quantidade de mulheres neste serviço, conforme pesquisa realizada por Dantas e Zanello (no prelo) em que foram entrevistadas nove mulheres deste mesmo serviço. Este achado confirma o dado apontado pela OMS que a depressão tem se apresentado três vezes mais comum em mulheres do que nos homens (Who, 2012).

Inicialmente, foi realizada uma entrevista aberta, conduzida pela pesquisadora, usando apenas duas perguntas disparadoras: "Conte-me sua história de vida", e "Fale- 
me da sua depressão". O paciente foi interpelado a falar livremente. Ao final, foram perguntadas questões acerca do conteúdo que o próprio paciente trouxe, através de frases como "Fale-me um pouco mais sobre isso" ou "Como assim?".

Cada entrevista durou, em média, uma hora e meia com cada participante. As entrevistas foram realizadas no próprio hospital, em sala de clínica de psicologia e nas dependências da universidade (sempre em lugares onde o sigilo fosse assegurado). As entrevistas foram gravadas por meio de aparelho eletrônico do tipo gravador de voz digital. Foi realizada a transcrição das entrevistas.

Depois de transcritas, as entrevistas foram analisadas, no período de fevereiro a abril de 2016, pela mestranda e pela orientadora e, no caso de dois participantes, foi necessário realizar uma outra entrevista para esclarecer dúvidas ou lacunas sobre a primeira entrevista. Esta segunda entrevista durou em média 1 hora e 30 minutos para cada um dos dois participantes. Uma delas foi realizada em uma sala na universidade e outra em consultório de psicologia. A segunda entrevista também foi transcrita, analisada e utilizada para levantamento dos dados.

Para a análise interpretativa, utilizou-se a perspectiva dos estudos sobre as masculinidades inspirada nas categorias de análise oriundas de diversos pesquisadores/as, tais como Badinter (1993), Connell (2005), Welzer-Lang (2001, 2004) e Zanello (2016), bem como de contribuições da perspectiva psicodinâmica.

A pesquisa seguiu as normas e princípios estabelecidos na resolução CNS 196/96 e foi aprovada pelo Comitê de Ética do Instituto de Ciências Humanas da Universidade de Brasília, registrado sob $\mathrm{n}^{\mathrm{o}}$ CAAE: $47775615.9 .0000 .5540 \mathrm{em}$ 28/09/2015. (conforme Anexo 1). 


\section{DEPRESSÃO EM HOMENS: MASCULINIDADES DESEMPODERADAS}

A seguir serão apresentadas as histórias de vida e a análise de cada um dos três entrevistados.

Luiz: Pau, "de arara", para toda obra

Luiz $^{14}, 70$ anos, identifica-se como pardo e heterossexual, tem três filhos, todos/as com mais de 40 anos. Nasceu no interior do Nordeste e mora em uma das principais regiões metropolitanas do país com a esposa e a filha. Não concluiu o Ensino Fundamental quando morava na cidade natal e se aposentou com uma renda maior que três salários mínimos. Chegou a essa região por volta dos seus 18/19 anos de idade, e logo se casou. Em seguida, começou a trabalhar na construção civil até se aposentar.

Luiz trabalhava quando criança no sustento da casa; conta, por exemplo, que carregava tijolos para construção e transportava no jumento. Apesar da dificuldade econômica, Luiz relata ter sido triste a partida da terra natal. Ao contar sobre a mudança de cidade menciona a música Triste Partida de Luiz Gonzaga ${ }^{15}$. Tais trechos dizem bastante da história dele: “Em um caminhão, ele joga a familia, chegou o triste dia, já vai viajar, meu deus, meu deus.... saudade de mói, e as água nos olhos, começa a cair, ai, ai, ai, ai, do mundo afastado, ali vive preso, sofrendo desprezo, devendo ao patrão, meu deus, meu deus".

Nos anos 60, Luiz chega do Nordeste em um pau de arara, em uma viagem de 36 dias, ele e mais oito irmãos. Ele se refere ao local como um verdadeiro canteiro de obra: "O que existia aqui eram obras, construção civil. Muito trabalho... aqui não se via uma

\footnotetext{
${ }^{14}$ Para todas as pessoas entrevistadas, foram utilizados nomes fictícios escolhidos pela pesquisadora. No caso dele, escolhi o nome de Luiz para fazer uma homenagem feita por ele ao cantor Luiz Gonzaga durante a entrevista. E para todos os casos, todas as informações que pudessem caracterizá-los foram omitidas ou substituídas por informações mais gerais para preservar o sigilo dos interlocutores.

${ }^{15}$ A música na íntegra foi incluída por dizer muito da história de Luiz referente à vinda do Nordeste (Anexo 2).
} 
pessoa vendendo laranja na rua, vendendo picolé na rua... era trabalhador por todos os lados". Ao chegar na capital, trabalhou na construção da nova cidade.

Sua chegada à cidade apresenta elementos comuns à análise feita por Pereira (2014) em sua tese de doutoramento. Por meio da investigação da história de vida de oito homens que saíram do campo rural para a cidade, no Piauí, a autora aponta inúmeras dificuldades pelas quais passaram, tais como fome, perda de vínculos familiares, doenças que impactaram a vida financeira e laboral, sem nenhum amparo do Estado. Ou seja, há aspectos sócio-econômicos importantes que impactam a trajetória de certas masculinidades em suas interseccionalidades com classe social e raça. Luiz relatou, neste sentido, o racismo enfrentado por ser negro e também o trabalho árduo por ser operário da construção civil.

Conheceu sua esposa, alguns meses depois que chegou à cidade. Ela, nascida, também no Nordeste, foi, segundo ele, a "namorada séria". Luiz se esforçou para comprar um terreno, pois segundo suas palavras: "quem casa quer casa". Em seguida, eles se casaram, construíram uma casa e tiveram filhos. Sua primeira filha nasceu logo após o casamento. Para ele, o preço foi alto de deixar sonhos de lado para tornar-se o provedor da família. Trabalhou duro. Conta que a esposa teve uma vida tão sofrida, difícil, quanto a dele ou até mais, por conta da pobreza e da família que deixou para trás no Nordeste. Ela se dedicou à casa e aos filhos, cabendo a ele todo sustento da família.

Apesar do esforço em cumprir com a virilidade laborativa e com o papel de provedor, a vida amorosa também se mostrou árdua. Cabisbaixo e com muita vergonha, Luiz conta que não experimentou satisfação e realização sexual no casamento. Segundo ele, a esposa tinha odores que o incomodavam, e, ao conversar com ela, não houve qualquer tentativa de solucionar o problema. Isto se deu desde o segundo ano de casamento e perdura até os dias de hoje. Também não houve cumplicidade, pois, 
segundo ele, a esposa teve problemas com a família de origem quando jovem e tinha dificuldades de conversar e compartilhar coisas pessoais (afetos). Ambivalente, ele ressalta que ela foi uma mãe dedicada aos filhos, mas, por outro lado, ressente-se por ela ter se centrado demais na educação dos mesmos. Sua fala aponta para um casamento feito com a "mãe de seus filhos", mas a ausência de uma companheira, com cumplicidade afetiva e sexual. Luiz buscou parceiras fora do casamento, caracterizando o que Lagarde denomina de "poligamia consentida" (Lagarde, 2011).

Ele menciona que queria ter estudado quando criança, porém não havia essa preocupação ou esse objetivo. Lamenta não ter arrumado tempo e nem ter se esforçado para retomar os estudos na fase adulta. Diz que gostaria muito de ter tido um emprego estável no serviço público e ter se aposentado por ele. Em sua narrativa, ora se mostra ressentido consigo mesmo por ter se acomodado e não ter tido coragem, garra, determinação para estudar e ter um emprego melhor; ora pensa que o dinheiro poderia tê-lo transformado em um homem ruim: "sabe-se Deus lá que que poderia ter acontecido se eu tivesse me tornado um empresário"; ora se orgulha pela vida dos filhos: dois deles são servidores públicos.

Os sentimentos de culpa e comparação com outros homens estão fortemente presentes: ele se compara com colegas que, inicialmente na mesma situação que a sua, cresceram economicamente e se ressente por não ter aproveitado uma oportunidade de ascensão em uma construtora em que trabalhou. A competição, a comparação, o ter que demonstrar coragem, autodomínio, firmeza e resistência estão ligadas à virilidade (Courtine, 2013) e ao projeto hegemônico das masculinidades (Connell, 2005). Há também um grande embate consigo mesmo, marcado pela tonalidade da culpa: culpa por não ter estudado, culpa por ter falhado e não ter atingido o ideal laborativo presente nas masculinidades (Connell, 2005; Welzer-Lang, 2001; Zanello \& Bukowitz, 2011; 
Zanello, 2016). Esta culpa aponta para o funcionamento superegóico cujo ideal, gendrado, não foi cumprido. Além disso, a culpa está ligada à sensação de que poderia ter feito diferente, ou seja, a um lócus de controle interno, atribuindo a falha ou a impotência a si próprio, o que é mais característico nos homens, em nossa cultura (Corbin, 2013; Zanello \& Bukowitz, 2011).

Os filhos, como já apontamos, são motivo de orgulho para Luiz, dentre outras razões, porque eles conseguiram alcançar aquilo que Luiz deixou escapar em sua vida: terminar "os estudos", se formar e se tornarem servidores públicos. Como aponta Freud $(1914)^{16}$, quando os filhos conseguem alcançar aquilo que os pais almejam, os pais reproduzem o próprio narcisismo projetado nos filhos, como aquilo que se foi perdido e que gostaria de ter sido. Deus passa a ser invocado por ele ter constituído uma família e sobrevivido em uma cidade que não era a sua terra natal, como ele mesmo fala: "filhos como bênção de Deus". A experiência religiosa também se apresenta como um importante fator de apaziguamento de seus conflitos, por exemplo, quando ele fala das crises depressivas: "eu sempre peço que Deus abençoe e que Deus abençoe os profissionais de saúde, que nós, cidadãos do dia a dia precisamos tanto deles... isso tem me ajudado... com a esperança de que eu não vou piorar, que eu não vou ter mais crise". E quando se refere à esposa e à vida sexual: "sem rancor, sem mágoa, são lembranças assim que poderia ter sido diferente, poderia ter sido uma maravilha, mas não foi do jeito que eu imaginava foi assim que foi e hoje tô inteiro aqui, ela também tá, graças a Deus temos os filhos bons, maravilhosos e eu acho que isso conta muito né”.

Um dado importante de sua história é que sua primeira crise aconteceu em um evento comemorativo de família, em que também estavam presentes alguns amigos do filho. Luiz, que sempre prepararam a refeição nos eventos de família, deixou nas mãos

\footnotetext{
${ }^{16}$ A teoria freudiana é utilizada em alguns momentos como inspiração para pensar as histórias, a teoria não foi utilizada como norte teórico e de forma aprofundada para discutir a respeito das masculinidades.
} 
de um filho esta responsabilidade. No entanto, o filho não preparou a comida a tempo, $\mathrm{e}$ Luiz e os amigos do filho passaram fome: "ele esqueceu que as pessoas vieram também para comer, como era de praxe... me incomodou bastante... aquela coisa assim no peito... uma palpitação forte... ai começou essa história dessa depressão". Luiz fala que se sentiu desrespeitado pelo filho, demonstrando grande frustração pela falta de cuidado, bem como tristeza pela perda de valor e de atenção por parte deste filho. A partir deste evento, Luiz começou a sentir palpitações, tristeza, dor no peito e vontade de não existir mais, diz que planejou suicídio em outro momento, mas que logo desistiu do ato. A partir deste relato, parece ter iniciado uma trajetória de impotência existencial diante de si, da família e da vida.

Nas narrativas de Luiz, o verbo poderia ter sido está muito presente. Ele está com 70 anos, é o filho mais velho e sente que foi um escravo do trabalho, porém sem ascender ao status e à condição financeira que gostaria e o deixaria no mesmo patamar dos colegas com quem se compara. Conta que sofreu preconceito por ser nordestino, menciona ter sofrido racismo e diz ter tido uma vida muito sofrida. É como se ele fosse um pau para toda obra, porém um "pau de arara".

A virilidade laborativa não o empoderou dentro dos ideais hegemônicos e naquilo que considera que poderia ter feito. Como apontam Zanello, Silva e Henderson (2015a): o envelhecimento coloca em xeque, de forma diferenciada, homens e mulheres. Hoje, aos 70 anos, ele sofre pelo futuro pretérito, pela oportunidade que julga ter tido e pelo homem que ele não pôde ser. Os dois elos de investimento que sobraram para Luiz foram a realização através da realização dos filhos e a Igreja. 
Maurício: A desilusão da medicina como propiciadora da masculinidade hegemônica

Maurício, 26 anos, se identifica como negro e heterossexual, é solteiro e não tem filhos. Nasceu e mora no Centro Oeste do país em uma república, com colegas do curso de medicina. Mudou-se para uma outra cidade do Centro Oeste quando foi aprovado no vestibular em uma universidade pública e está cursando atualmente o penúltimo ano do curso (internato). Conta com o apoio financeiro do pai e trabalha como professor particular de conteúdos do curso de medicina há aproximadamente 1 ano. Menciona que para seu sustento possui uma renda média superior a três salários mínimos.

A trajetória de ingresso para o curso de medicina em uma universidade pública, geralmente, exige muito estudo e dedicação, ainda mais no caso dele por se tratar de um curso bastante concorrido. Maurício prestou o exame do vestibular em algumas universidades até ser aprovado. Apesar do ingresso em uma grande universidade federal, ele lamenta a aprovação pelas cotas raciais: "eu sempre fui contra eu poder ter acesso às cotas raciais né, porque eu, poxa, sempre tive acesso ao ensino de qualidade, então eu acho que não tem o porquê de eu acessar por esse meio, né, Só que eu vi que com a minha nota provavelmente eu passaria pra Medicina se eu tivesse entrado pelas cotas raciais, naquele ano. Chegou ao final do ano, acabei me decepcionando nas segundas fases assim, aí decidi que vou prestar para esta universidade e vou colocar as cotas raciais, né. Aí passei aqui, né... (...) como se eu não me sentisse plenamente no direito de estar aqui, né, pelo fato de em um momento eu considerar que não é justo, né". E ele expressa também que: “A primeira situação foi essa, né, de ter que me conformar com essa minha fraqueza, né. Poxa eu tinha o ideal, né. Poxa eu tinha condição, não acho justo e mesmo assim eu não abri mão, né. E pensei se não for eu, 
vai ser outra pessoa". Os sentimentos de fraqueza e culpa, e de se sentir ineficaz no desempenho universitário perpassam a trajetória de Maurício, sentimentos estes nos quais participa o ideal das masculinidades (Corbin, 2013; Courtrine, 2013; Zanello, 2016).

Maurício encarava até então o curso de medicina como garantia de acesso à "prateleira do amor" (Zanello, 2016), ou seja, a uma vida universitária que idealmente seria admirada pelas mulheres, as quais em sua fantasia desejariam "ficar" com os estudantes de medicina por ser um curso com status na sociedade brasileira. Sonhava também que o curso possibilitaria um acúmulo rápido de dinheiro, vindo em parte pela família (em seu reconhecimento por ter passado em um vestibular tão concorrido) e, em parte, pelo curso. Segundo suas próprias palavras: "E sempre idealizando muito o objetivo do curso de medicina, né, porque minha vida ia ser mil maravilhas, né, depois que eu passasse pra medicina (...) Eu achava que a vida ia ser muito melhor, porque aí meu pai ia me dar um carro, e aí eu ia fazer Medicina. Um pensamento que eu acho assim bem, hoje, muito mesquinho de eu vou fazer Medicina, vou ter carro, vou ser foda, não sei o que, vou ficar com várias meninas esse tipo de coisa". O que se percebe em seus relatos é a expectativa de acesso a uma virilidade sexual e laborativa (financeira) propiciada pelas "promessas" que a chancela de um curso de status lhe proporcionaria e que se vê fortemente frustrada.

Ele relaciona assim o surgimento dos sintomas depressivos com o não cumprimento dessas "promessas": “É, assim eu estou te contando muito relacionado ao curso, minha vinda pelo curso, porque eu acho que isso tem muito a ver com o fato de eu estar aqui hoje, tomando medicação, ter procurado psicoterapia... porque na minha cabeça isso tudo começou a partir do momento que eu entrei na Medicina. 
Apesar de não ser como idealizado, Maurício relata que ainda conseguiu ficar com algumas garotas: " em relação a ficar com várias mulheres, eu até consegui, mas não porque eu fazia medicina, é porque eu decidi que eu queria ficar com muitas meninas, então eu tentava ficar com muitas meninas, então... acho que se eu fizesse qualquer curso eu teria ficado com várias meninas, então... é...” Em outros momentos, menciona as mudanças ocorridas quando inicia uma relação estável com a namorada atual: "E é, partiu de mim essa vontade, como se já estivesse o suficiente, acho que já curti o suficiente, tá bom, acho que estou afim de alguém que vai ser a minha companheira, né, alguém que vai estar comigo e que vai ser mais do que isso, um beijo na boca ou transar, ou seja lá o que for, né”.

Com o desenrolar do curso e o início da prática profissional, relacionada ao internato, Maurício expressa: "Mas sempre essa ideia de que não era suficiente, não era bom, que eu não estava aproveitando, de que se era pra ir lá e eu não aproveitar nada era melhor ficar em casa dormindo, né. E isso foi virando uma bola de neve, né.(...) Ou tem que ficar indo pro hospital, chega em casa, está cansado, deita e dorme, ou eu vou falhar, sabe, só que ao mesmo tempo o fato de eu não estar fazendo me dá revolta. Eu cheguei uma época a insistir a vir, mas eu vi que não estava sendo suficiente”.

Ao não se sentir bom o suficiente tanto quanto seu ideal desejaria, ele se retira da prova de fogo. Ou seja, foge das situações que evidenciem estar em uma suposta "desvantagem". E quando não há como fugir, lida com sua frustração através da agressividade (Aronson, Wilson \& Akert, 2002), sobretudo com residentes ou profissionais do serviço onde estagia: “A impressão que eu tenho é que eu gosto de ficar afrontando as pessoas que se acham superiores a mim. E eu gosto muito de afrontar. Eu tenho tentado enxergar os meus erros também. Mas eu continuo sempre 
querendo bater de frente, mesmo com quem é nitidamente mais forte do que eu, então tem essa questão de querer enfrentar e não aceitar, né. E às vezes quando eu... o adversário é muito forte eu me boicoto né, sumo, não consigo persistir nessa situação". Em suma, Maurício demonstra dificuldade de comparecer na vida quando sente que vai falhar ou ficar impotente em face de um ideal de masculinidade que é mantido na relação com os pares (Badinter, 1993; Connell, 2005), bem como através do funcionamento narcísico que é sempre gendrado (Zanello \& Bukowitz, 2011).

Os pais de Maurício não moram na mesma cidade que ele e enquanto ele estava se preparando para o exame do vestibular, eles se separaram. A entrada no curso de medicina coincidiu também com um forte desapontamento e decepção com a figura de seu pai. Segundo ele, três fatores se fizeram aqui presentes: o primeiro, foi por ter descoberto que o pai se relacionou com várias mulheres quando ainda casado com sua mãe em uma relação que supostamente seria monogâmica; o segundo fator, ocorreu quando o pai se casou novamente: a partir de então, este pai não o amparou financeiramente como antes da separação (o que acarretou, por exemplo, em não lhe dar o carro tão sonhado); e o terceiro fator se deu devido ao afastamento afetivo do pai, as saudades e a falta de um convívio com ele. Em muitas falas, Maurício se diz parecido com o pai quanto às características de ser desorganizado financeiramente, de ter dificuldade de aceitar críticas e a tendência de fugir dos problemas, o que julga ser uma irresponsabilidade de ambos.

Foi necessário chegar ao fundo do poço para se permitir solicitar ajuda da mãe e buscar um tratamento psiquiátrico: "Eu só tinha vontade de ficar dormindo, não tinha vontade de fazer nada, aquela sensação de que tudo era sem graça, né. Aí eu lembro até do dia que eu liguei pra minha mãe, chorando, e falei assim 'mãe, eu não suporto mais'. E não tinha exatamente uma causa assim tão específica, sabe, tipo é isso que 
está me fazendo mal. Hoje eu penso que seja o curso que está me fazendo mal, né, mas eu cheguei a um ponto de que eu não me sentia bem pelo fato de não estar comparecendo às atividades, mas eu não comparecia às atividades porque comparecer não me fazia bem também, né. E então eu comecei a sofrer muito por isso, chorei bastante, ai liguei pra minha mãe e falei assim 'oh, mãe, primeira vez na minha vida que eu acredito que eu só vou sair do fundo do poço se eu tomar uma medicação, porque eu só consigo ficar deitado nessa cama, não quero fazer mais nada na minha vida, quero só ficar deitado, não quero fazer mais nada'”.

Maurício relata a relação entre o uso da medicação e de suas relações sexuais com a namorada, queixando-se do quanto ele se sente impotente. Segundo ele, ao usála, sua libido diminuiu e, por esse motivo, ele parou de tomar o remédio por conta própria. Posteriormente, decidiu procurar ajuda especializada no ambulatório de psiquiatria do hospital, justamente porque sem a medicação (antidepressivo) ficou ansioso e, dentre outros sintomas, passou a ter ejaculação precoce nas relações sexuais, ficar mais agressivo e brigar com as pessoas.

Segundo ele, sua namorada tem o ajudado muito nessas negociações entre o que idealizou e a realidade. Em nossa perspectiva: na elaboração do luto do ideal de uma masculinidade hegemônica para outra possível. Isto implica em assumir as próprias responsabilidades financeiras, aceitar seus limites e de diminuir as expectativas referentes ao pai. Ele menciona: E com ela eu consegui enxergar mais o tanto de culpa que eu tenho nisso, né, o tanto que eu fico me vendo como vítima e não tenho feito nada pra melhorar, né. Então esse relacionamento foi excelente nesse aspecto. Então acho que esse momento tem sido de muitas mudanças na minha vida, assim. Internato, que a carga horária é bem maior, a exigência é bem maior, né, e eu começando a me descobrir, enxergar minhas responsabilidades, ver minhas limitações e tenho muito que 
evoluir ainda, tenho muita coisa pra melhorar, mas é isso assim. Tenho notado essa semelhança com meu pai mais recentemente, essa semelhança com aspectos negativos, né. Aspectos positivos eu já tinha reparado antes. A familia repara né, ah você parece com seu pai".

Em suma, percebemos na história de Maurício uma grande frustração pelo não exercício de uma possível performance sonhada, idealizada, dentro da masculinidade hegemônica (acesso à prateleira do amor, dinheiro e status), a qual seria propiciada idealmente pela entrada no curso de medicina. Além disso, seu desempenho no curso apesar de não ser ruim, o coloca em perspectiva com outros alunos que têm um desempenho melhor. Ou com outros profissionais que, apesar de estarem em outro estágio da carreira, são ressentidos como rivais. O luto que se opera é da ordem do ideal, não por ser pequeno, mas por não ser grande o quanto se gostaria. Um aspecto positivo é que Maurício parece ter encontrado na relação amorosa o espaço para poder "falhar" e ser cuidado. Ter uma parceira pode ser um bom fator de proteção à saúde mental dos homens, como levantamos em outro estudo (Windmöller \& Zanello, no prelo).

Eduardo e o "quase": quase bom filho, quase namorado, quase formado

Eduardo, 25 anos, se identifica como branco e bissexual, não tem filhos e é solteiro. Nasceu e mora na periferia de uma capital brasileira. Vive na mesma casa desde os dois anos de idade com a sua mãe. Está cursando Arquitetura em uma universidade pública e estudou Farmácia, durante três anos, sem concluir o curso, em outro campus universitário. Sem renda própria, conta com renda familiar superior a três salários mínimos. 
Eduardo identifica um episódio marcante em sua vida, o qual julga ter tido grande impacto afetivo: na sexta série, ele mudou de uma escola pequena para uma escola maior. Ao sair de uma escola com ambiente mais familiar, para outra mais impessoal, sentiu-se desamparado, pois nesta escola sofreu vários tipos de assédio: "era como seu tivesse saído da província para a metrópole". Quando perguntado sobre estas situações, ele não conseguiu relatar. Eduardo recorda cenas de isolamento vividas com sentimentos depressivos (traduzidos por ele) e sem se sentir apoiado pelos pais. Ele sublinha: "talvez eu tenha perdido o rumo ali".

No que diz respeito aos conflitos escolares, estes comparecem na sua história até os dias de hoje. Na vida acadêmica atual, ele conta que tem crises de ansiedade quando se lembra do curso de farmácia e o compara com o curso de arquitetura. No curso de farmácia, ele se sentia entre iguais, pois é oferecido em outro campus, e lá os alunos levavam uma vida parecida com a dele como ele mesmo diz: "na Farmácia tem muita gente de ensino público". Já o curso de arquitetura é no campus localizado em um bairro nobre da capital e ele relata que se sente inferior devido à renda da sua família: "assim minha família não tem grana, né, só trabalha eu e minha mãe, sempre pouco dinheiro (...) qual chance eu tenho... essa questão monetária, social pesa muito, sabe?”

No curso de farmácia além de ter se sentido entre pares, ele teve uma namorada, a única em sua vida até o presente momento. Porém, ambivalente, ele relata ora ter evitado conhecer a família da ex-namorada por vergonha de sua condição socioeconômica (pois se comparava com o namorado da irmã da namorada que tinha um status social, com bom emprego e carro), e ora se ressente por não ter sido apresentado à família dela. De qualquer forma, já se sentia aquém das expectativas, suas e dos outros, no que tange a uma performance masculina chancelada pelo dinheiro e carro como sinônimos de poder e sucesso. Em seu relato, apesar de quase um ano de 
namoro em que se manteve nesta relação, foi um "quase namorado", justamente por ter permanecido em uma esfera do segredo, sem ser assumido, nem se assumir para a família da garota.

Eduardo se arrepende pela mudança de curso, da farmácia para a arquitetura. Não porque não goste, mas por ser colocado em xeque em pontos nos quais se julga muito vulnerável: a diferença da situação econômica com os outros colegas, por um lado; e, por outro, a alta exigência narcísica marcada por um ideal de desempenho frustrado. Não que seja um aluno ruim, mas não é tão bom, e principalmente, não é tão reconhecido como gostaria. Diz que quer criar projetos urbanísticos diferentes, ousados, revolucionários, que ressignifiquem a diferença social/econômica pela qual sofre em relação a seus colegas: “eu gostaria de tá formado, pós graduado para ser um professor da primeira turma do curso de arquitetura (na cidade onde mora) e lembrasse o discurso fora dessa cidade projetada. (...) às vezes fica empolgado com o curso. (...) com o projeto urbanístico (da cidade onde mora) tomo as dores".

Tem tido crises de pânico (descritas por ele como ataques de ansiedade, raiva e crises de choro) durante a execução de atividades acadêmicas, bem como no estágio profissional. Ele, recentemente, abandonou um projeto científico importante do qual participava e relata como tem sido difícil dedicar-se ao curso. Define-se assim: "Sou um proscratinador muito sem vergonha".

$\mathrm{Na}$ faculdade de arquitetura atual conheceu uma menina por quem se apaixonou. Nem chegaram a ficar juntos. Relata que fez tudo errado, pois nem tentou conquistá-la devido achar que seria impossível a menina gostar dele. Sofreu e sofre zombaria dos amigos quando este assunto vem à baila, por exemplo, quando encontra a menina pelos corredores da universidade (é interpelado à "voltar" às performances da "casa dos homens"). Relata que essa sensação de menos valia sempre esteve presente em suas 
relações, afinal o que teria para "oferecer"? "Quando eu sou bem aceito, num relacionamento ou num grupo de amigos, às vezes sempre vem aquela sensação de que, pô isso vai desmoronar a qualquer momento, sabe? Isso... fico com sensação meio... kafkaliana assim que não é verdade sabe? Que não é...será que aconteceu mesmo? Fico meio nessa...sem chão, sabe?" Trata-se de um sentir-se inadequado, aquém, inseguro e um tanto pessimista quanto a sua imagem perante o mundo (como homem "falho"); aos relacionamentos afetivos e familiares; à vida escolar pregressa; à acadêmica atual; ao futuro como profissional de arquitetura e homem formado.

Possui uma relação conflituosa tanto com a mãe como com o pai biológico. É fruto da relação extraconjugal de seu pai com sua mãe. Não conhece a família paterna. Para Eduardo a relação com a mãe é "burocrática", sem afetos e racionalidade esperada: “minha mãe não consegue conversar comigo sobre projetos e ideias profissionais (...) não sai nada da conversa". Quando fala do pai, ele se recorda da infância: "meu pai me estimulou a observar muito, a ver as coisazinhas, a olhar para o mundo de uma forma mais cientifica mais racional da coisa" (...) "essas coisinhas que acho que se perdeu com ele e que eu não tive com outras pessoas da minha familia". A relação afetiva com o pai foi se perdendo logo ainda na infância, quando esse pai deixa de buscá-lo na escola, bem como quando deixam de fazer passeios nos finais de semana.

Apesar de sua queixa a respeito da relação burocrática com a mãe, diz que a causa de estar vivo se deve exclusivamente a ela e, mesmo assim, segundo ele, não é uma causa muito boa: se sente um fardo, pois não consegue comparecer com o apoio financeiro em casa. Aqui, novamente, se vê impossibilitado de exercer uma performance prescrita na masculinidade hegemônica (Connell, 2005; Welzer-Lang, 2004; Zanello, 2016). 
Na segunda entrevista, Eduardo contou que cansou de ser espectador da própria vida e que está decidido a morrer de forma planejada e racional. Fala que está planejando se suicidar e queria muito poder fazer a eutanásia e "ter o direito de morrer". Segundo ele, as crises de ansiedade, raiva e de choro têm piorado nos últimos dois meses. Queixa-se: "fiquei para trás". Relata que seus amigos estão se casando e se "dando bem", arrumando bons empregos e comprando imóveis, ou seja, signos reconhecíveis de uma "boa" performance no ideal da masculinidade hegemônica (Welzer-Lang, 2004; Zanello, 2016). A intensa luta interna, marcada por uma cobrança do que não é (em função do que deveria e poderia ser), bem como a comparação com seus amigos, levam-no à exaustão emocional: "por dentro eu acho que tô sempre um caco". Ao final do encontro, foi oferecido apoio psicológico devido ao total desamparo apresentado, o que não foi necessário segundo ele, pois já vem sendo acompanhado pelo serviço de psicologia e psiquiatria.

Depreende-se das entrevistas, que Eduardo está sempre no "quase" (quase formando, quase filho "de verdade", quase namorado, etc). Por querer estar além (mediado por um forte ideal narcísico), ele se sente sempre aquém como "homem": falta-lhe o exercício das performances laborativa e sexual. Não podendo cumprir o ideal, ele se retira do real, do se colocar à prova, levando-o a se sentir não apenas ineficaz, mas incapaz: "quando chego no curso, acabou tudo sabe? (...) às vezes é melhor nem tentar do que o fracasso certo, né?(...) você estragou tudo” (...) Será que eu mereço isso? Insira um adjetivo negativo na lacuna (...) eu avisei você para não tentar (...) o contexto é o mesmo, acho que o adjetivo é sempre incapaz”. 


\section{Tecendo histórias deprimidas no masculino}

A depressão vem como uma falha na agência pessoal das masculinidades. Utilizando metáforas de dois dos entrevistados: a depressão é como um fiasco; um projeto que desmorona, que não deu certo. A fala de fiasco vem de Luiz e a de desmoronamento vem do Eduardo. Os três não colocam em xeque o próprio narcisismo quando acham que vão falhar (melhor fazer um luto do que poderia ter sido do que tentar/arriscar); Luiz não se arrisca em um cargo novo em uma construtora; Maurício e Eduardo abandonam atividades acadêmicas que julgam difíceis e que não poderiam cumprir com o êxito esperado.

Em todas as histórias narradas percebe-se que falta uma consciência de gênero, eles não percebem o quanto do sofrimento deles tem relação com a constituição das masculinidades (normativas e hegemônicas), com as cobranças sociais de endurecimento do corpo, de provar ser macho, de ter que exercer uma virilidade sexual e laborativa a todo custo.

No caso do Eduardo, ele conta que os profissionais de psicologia e psiquiatria que lhe assistem não falam sobre a temática de gênero na sessão de terapia e que na sua avaliação são assistências pouco resolutivas, pois ele não consegue entender a causa da depressão, e se pergunta se este estudo pode lhe ajudar. Já o Maurício relata que em sua avaliação este projeto parece ser interessante, o que condiz com o que foi expresso em suas próprias palavras: "É, eu acho que os homens, em geral, têm muita dificuldade de assumir suas fraquezas, né. Ele acha que tem que ser forte, que tem que ser a rocha, tipo ah, eu sou o homem, né. Eu acho que as pessoas mais velhas, e algumas culturas, o homem realmente tende a não procurar muito o serviço de saúde, né, ele nega muito a doença dele, ele nega que ele precisa de ajuda e de apoio. Eu acho que, no meu caso, acho que conforme a escolaridade aumenta, o convivio, que nem, na universidade acho 
que eu tive muito contato com essa questão de quebrar esses paradigmas, esses preconceitos, acho que a universidade modificou muito a minha relação com isso. Quando eu entrei eu era uma pessoa muito mais preconceituosa. Coragem se constrói na formação de um verdadeiro macho. Mas ainda acho que, se eu fosse uma mulher, teria procurado antes. Ainda me sustentei muito".

Como apontamos nos três casos, o sofrimento, configurado na "depressão", parece vir mediado por um ideal de virilidade laborativa e sexual, o qual deve ser compreendido não apenas como uma cobrança social (apesar de ser por ela mantida, pelos pares), mas também de algo que foi se constituindo nestes sujeitos. Como afirmam Pereira (2014), Vigoya (2007) e Welzer-Lang (2001) os homens são fatores de risco para a própria saúde e para outros homens. Deve-se levar em conta, também, a faixa etária do sujeito, pois o dispositivo da eficácia parece ser interpelado de forma diferenciada nas diversas fases da vida (Zanello, Silva \& Henderson, 2015).

Levando em consideração a faixa etária do Maurício e do Eduardo, o que está em jogo é o futuro profissional, pois estão cursando nível superior e projetando uma carreira. Nesta seara, Eduardo é quem parece estar com menos fatores de proteção, pois se compara com os colegas do curso de arquitetura que tem um poder socioeconômico maior (como apontamos, ele mora em uma cidade satélite) e, além disso, por não ter mãe e pai que o apoiem na carreira, o que lhe provoca uma forte sensação de desamparo. No caso de Maurício, a namorada passou a funcionar como fator de proteção à sua saúde mental, ajudando-o a fazer negociações entre suas expectativas idealizadas e a possibilidade de uma performance real (e aceita) de masculinidade. Luiz, por seu turno, já aposentado e em outro momento da vida, sofre com a carreira que não teve, pela carga de ter sustentado sozinho uma família, ter trabalhado muito (como um "escravo do trabalho") e sem grandes realizações na vida amorosa e sexual com a 
esposa. Sua fala é direcionada não a um futuro que poderá não advir, mas de um passado que não foi, de um pretérito imperfeito, o qual não pode mais resgatar.

Pensar a depressão sob o viés das masculinidades permite refletir como os homens, em nossa cultura, são subjetivamente colocados em xeque de forma diferenciada em relação às mulheres. Faz-se necessário desenvolver mais estudos sob este enfoque, bem como pensar em possibilidades de intervenções psicoterapêuticas que levem em conta o gênero e a construção de outras performances menos sofridas, de masculinidades possíveis.

\section{CONSIDERAÇÕES FINAIS}

Esta pesquisa teve como objetivo ouvir a história de vida narrada por três homens diagnosticados com depressão, para compreender como as masculinidades participaram e participam na configuração de seus sofrimentos. Foi utilizada para análise o método de histórias de vida, interpretadas sobre análises casadas de gênero e saúde mental, inspiradas brevemente pela abordagem psicodinâmica.

Nos três casos analisados, pôde-se perceber a participação da exclusão da possibilidade de uma performance prescrita na masculinidade hegemônica como um fator propiciador de grande sofrimento psíquico. Isto se deu, sobretudo, através da (impossibilidade) da afirmação da virilidade laborativa e sexual, ou seja, do dispositivo da eficácia. Quanto aos conflitos amorosos, nota-se uma diferença quanto às mulheres, nos três casos eles sofrem por não terem sido ou eficazes na conquista amorosa ou por não terem exercido a virilidade sexual almejada nas relações vividas, ao contrário das mulheres que sofrem pelo dispositivo amoroso por não terem sido escolhidas e validadas pelo olhar masculino (Zanello, 2016). Encontramos também diferenças na 
configuração deste sofrimento, a depender do momento de vida no qual se encontra o sujeito, bem como interseccionalidades importantes com classe social e raça.

Faz se necessário destacar alguns limites da presente pesquisa. Em primeiro lugar, o número limitado de sujeitos entrevistados. E em segundo lugar, o gênero da entrevistadora que, se de um lado pode ter ajudado a abrir certas questões, por outro pode ter impedido o acesso mais profundos a certos temas, os quais funcionar na casa dos homens (interpelado por um entrevistador homem, por exemplo) deixaria mais evidentes.

Em conclusão, levando em consideração as limitações dos grandes manuais psiquiátricos (CID E DSM) quanto à leitura dos marcadores de gênero, raça e classe na construção do diagnóstico de depressão ou de outras psicopatologias, pensar a saúde mental de homens sob o viés de gênero, pela perspectiva das masculinidades, pode levar a uma releitura e qualificação de seu sofrimento, bem como possibilitar o delineamento de intervenções e estratégias de prevenção mais específicas e, talvez, com maior eficácia.

\section{REFERÊNCIAS}

Amantino, M. \& Freire, J. (2013). História dos homens no Brasil. In M. D. Priore; M. Amantino (Org.), Ser homem... Ser escravo (pp.15-48). São Paulo: Unesp.

Aronson, E., Wilson T. D., Akert, R. M (2002). Psicologia Social. Rio de Janeiro: LTC Editora.

Badinter, E. (1993). XY Sobre a identidade masculina. Tradução Maria Ignez Duque Estrada. Rio de Janeiro: Nova Fronteira, 1993 (Original publicado em 1992).

Canguilhem, G. (2009). O normal e o patológico (6a ed.). Rio de Janeiro: Forense Universitária.

Connell, R. W (2005). Masculinities (2a ed.). University of California Press: Berkeley. 
Connell, R. W. \& Messerschmid, J. W. (2013). Masculinidade hegemônica: repensando o conceito. Estudos Feministas, Florianópolis, 21 (1), 241-282. doi: http://www.scielo.br/pdf/ref/v21n1/14.pdf

Corbin, A. (2013). A obrigação da virilidade, fonte de ansiedade e angústia In A. Corbin, A., J. J. Courtrine \& G. Vigarello (Org). História da virilidade. O triunfo da virilidade. O século XIX. Volume 2: Vozes.

Courtrine, J. J. (2013). Introdução. Impossível virilidade In A. Corbin, J. J. Courtrine \& G. Vigarello (Org). História da virilidade. O triunfo da virilidade. O século XIX. Volume 2: Vozes.

Dantas, G. C., Zanello, V. (no prelo). Mulheres e Depressão: Vivências sob a perspectiva de gênero da $3 \mathrm{a}$ Onda.

Fanon, F. (2008). Pele negra, máscaras brancas. Salvador: EDUFBA.

Farmer, P. (2002). On suffering and structural violence: a view from below. In: J. Vincent (Org.). The antropology of politics: a reader in ethnography, theory and critique (pp. 424-437). Oxford: Blackwell.

Figueroa-Perea, J. G. (2016). Algunas reflexiones para dialogar sobre el patriarcado desde el studio y el trabajo con varones y masculinidades. Sexualidade, Salud y Sociedad. Revista Latino Americana, 22, 221-248. doi: http://www.epublicacoes.uerj.br/index.php/SexualidadSaludySociedad/article/view/22451/16119

Foucault, M. (2009). Microfisica do poder. Rio de Janeiro: Graal (Original publicado em 1979).

Freud, S. (2004). Escritos sobre a psicologia do inconsciente. À guisa de introdução ao narcisismo (pp.95-119). Rio de Janeiro: Imago (Original publicado em 1914).

Giffin, K. (2005). A inserção dos homens nos estudos de gênero: contribuições de um sujeito histórico. Ciência e Saúde Coletiva, 10(1): 47-57. doi: http://www.scielo.br/pdf/csc/v10n1/a05v10n1.pdf

Hernáez, A. M. (2000). What's behind the Symptom? On Psychiatric Observation and Anthropological Understanding in A. Kleinman (Org.). Harwood Academic Publishers.

Lagarde, M. (2011) Los cautiverios de lasmujeres. Madresposas, monjas, putas, presas y locas. Madrid: San Cristobal.

Lutz, C. (1985). Depression and the translation of emotional worlds. In A. Kleinman, B. Good (Eds.), Culture and Depression Studies in the Antropology and Crosscultural Psychiatry of Affect and Disorder (pp. 63-100). Berkeley Los Angeles London: University of California Press. 
Maluf, S. W (2010). Gênero, Saúde e Aflição: Políticas Públicas, Ativismo e Experiências Sociais In Maluf, S. W.; Tornquist, C. S. Gênero, saúde e aflição: abordagens antropológicas. Florianópolis: Letras Contemporâneas.

Minayo, M. C. D. S. (2014). O desafio do conhecimento pesquisa qualitativa em saúde. (14a ed). São Paulo: Hucitec.

Müller, A. P. D. (2010). O gênero no movimento da reforma psiquiátrica brasileira In Maluf, S. W.; Tornquist, C. S. Gênero, saúde e aflição: abordagens antropológicas. Florianópolis: Letras Contemporâneas.

Pereira, P. F. (2014). "Seja Homem”: Produção de masculinidades em contexto patriarcal. Curitiba, PR: CRV.

Szasz, T. S. (1976). A fabricação da loucura: um estudo comparativo entre a inquisição e o movimento de saúde mental. Zahar Editores: Rio de Janeiro.

Phillips, K. A. \& First, M. B. (2008). Gênero e Idade - considerações no diagnóstico psiquiátrico: agenda de pesquisa para DSM-V. In W. E. Narrow. et al (Org.), Capítulo 1 Introdução (pp. 3-5). São Paulo: Roca.

Pinho, O. (2014). Um enigma masculino: Interrogando a masculinidade da desigualdade racial no Brasil. Universitas. Humanística. 77, 227-250. doi: http://www.scielo.org.co/pdf/unih/n77/n77a10.pdf

Víctora, C. G., Knauth, D. R., Hassen, M. D. N. A. (2000). Pesquisa qualitativa em saúde: uma introdução ao tema. Porto Alegre: Tomo Editorial.

Vigoya, M. V. (2007). Teorías feministas y estudios sobre varones y masculinidades. Dilemas y desafíos recientes La manzana de la discordia, Diciembre, 4, 25-36. doi: http://manzanadiscordia.univalle.edu.co/volumenes/articulos/A2N4/art2.pdf

Welzer-Lang, D. (2001). A construção do masculino: dominação das mulheres e homofobia. Revista Estudos Feministas, Florianópolis, 9 (2), 460-482. doi: http://www.scielo.br/pdf/ref/v9n2/8635.pdf

Welzer-Lang, D. (2004). Masculinidades. In organização M. R. Schpun (Org.), Os homens e o masculino numa perspectiva de relações sociais de sexo (pp.107-128) São Paulo: Boitempo Editorial.

Widiger, T. A. \& First, M. B. (2008). Gênero e Idade - considerações no diagnóstico psiquiátrico: agenda de pesquisa para DSM-V. In W. E. Narrow. et al (Org.), Gênero e Critérios Diagnósticos (pp. 124-134). São Paulo: Roca.

Windmöller, N. \& Zanello, V. (no prelo). Depressão e masculinidades: uma revisão sistemática da literatura em periódicos brasileiros.

World Health Organization - WHO (2012). Depression: A Global Crisis World Mental Health Day. Occoquan: USA. 
Zanello, V., Bukowitz, B. (2011). Loucura e Cultura: uma escuta das relações de gênero nas falas de pacientes psiquiatrizados. Labrys, 20. doi: http://www.labrys.net.br/labrys20/brasil/valeska.htm

Zanello, V. (2014). A saúde mental sob o viés de gênero: uma releitura gendrada da epidemiologia, da semiologia e da interpretação diagnóstica In V. Zanello; A. P. M. D. Andrade (Orgs.), Saúde Mental e Gênero. Diálogos, Práticas e Interdisciplinaridade (pp. 41-58). Curitiba: Editora Appris.

Zanello, V., Silva, L. C., \& Henderson, G. (2015) Saúde Mental, Gênero e Velhice na Instituição Geriátrica. Psicologia, Teoria e Pesquisa, 31 (4). doi: http://www.scielo.br/pdf/ptp/v31n4/1806-3446-ptp-31-04-00543.pdf

Zanello, V., Fiuza, G., Costa, H. S. (2015a). Saúde Mental e Gênero: Facetas Gendradas do Sofrimento Psíquico. Fractal: Revista de Psicologia. doi: http://www.scielo.br/scielo.php?script=sci_arttext\&pid=S1984-02922015000300238

Zanello, V. (2016). Saúde mental, gênero e dispositivos. In: Dimenstein, M. (Org). Condições de Vida e Saúde Mental em Assentamentos Rurais. São Paulo: Intermeios Cultural. 
ANEXO 1

\section{DETALHAR PROJETO DE PESQUISA}

\section{$-$ \\ DADOS DA VERSÃO DO PROJETO DE PESQUISA}

Título da Pesquisa: Depressão e Gênero

Pesquisador Responsável: Gisele Cristine da Silva Dantas

Área

Temática:

Versão: 2

CAAE: 47775615.9 .0000 .5540

Submetido em: 17/08/2015

Instituição Proponente: Instituto de Psicologia -UNB

Situação da Versão do Projeto: Aprovado

Localização atual da Versão do Projeto: Pesquisador Responsável

Patrocinador $\quad$ Financiamento Próprio

Principal:

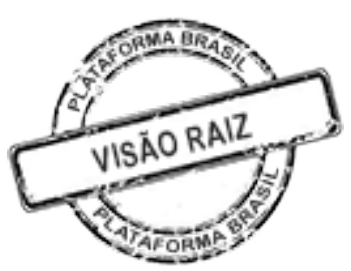

Comprovante de Recepção: PB_COMPROVANTE_RECEPCAO_526032

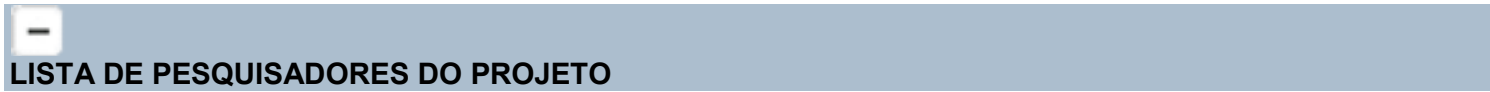

\begin{tabular}{|c|c|c|c|c|c|c|c|}
\hline CPF/Documento & Nome * & Atribuição & E-mail * & \multicolumn{2}{|c|}{ Currículo } & $\begin{array}{c}\text { Tipo de } \\
\text { Análise * }\end{array}$ & $\begin{array}{c}\text { Açã } \\
0\end{array}$ \\
\hline 635.117.971-87 & $\begin{array}{l}\text { Valeska } \\
\text { Maria } \\
\text { Zanello } \\
\text { de Loyola }\end{array}$ & $\begin{array}{l}\text { Equipe do } \\
\text { Projeto }\end{array}$ & $\begin{array}{l}\text { valeskazanello@uol.com. } \\
\text { br }\end{array}$ & $\frac{\text { Latte }}{\underline{s}}$ & $\underline{\mathrm{C}}$ & $\begin{array}{l}\text { PROPONENT } \\
\text { E }\end{array}$ & D \\
\hline 009.250.891-09 & $\begin{array}{l}\text { Naiara } \\
\text { Windmoll } \\
\text { er }\end{array}$ & $\begin{array}{l}\text { Assistente } \\
\text { da } \\
\text { Pesquisa, } \\
\text { Equipe do } \\
\text { Projeto }\end{array}$ & $\begin{array}{l}\text { naiarapsicologia@gmail.c } \\
\text { om }\end{array}$ & $\frac{\text { Latte }}{\underline{s}}$ & $\underline{\mathrm{C}}$ & $\begin{array}{l}\text { PROPONENT } \\
\text { E }\end{array}$ & D \\
\hline 573.175.501-91 & $\begin{array}{l}\text { Gisele } \\
\text { Cristine } \\
\text { da Silva } \\
\text { Dantas }\end{array}$ & $\begin{array}{l}\text { Contato } \\
\text { Científico, } \\
\text { Contato } \\
\text { Público, } \\
\text { Pesquisad } \\
\text { or principal }\end{array}$ & dantasg@hotmail.com & $\underline{\text { Latte }}$ & $\begin{array}{l}\mathrm{C} \\
\mathrm{V}\end{array}$ & $\begin{array}{l}\text { PROPONENT } \\
\text { E }\end{array}$ & $D$ \\
\hline
\end{tabular}




\section{ANEXO 2 \\ $\underline{\text { Triste Partida de Luiz Gonzaga }}$}

Meu Deus, meu Deus

Setembro passou

Outubro e novembro

Já estamos em dezembro

Meu Deus, que é de nós

Meu Deus, meu Deus

Assim fala o pobre

Do seco nordeste

Com medo da peste

Da fome feroz

Ai, ai, ai, ai

A treze do mês

Ele fez experiência

Perdeu sua crença

Nas pedras de sal

Meu Deus, meu Deus

Mas noutra esperança

Com gosto se agarra

Pensando na barra

Do alegre natal

Ai, ai, ai, ai

Rompeu-se o natal

Porém barra não veio

$O$ sol bem vermelho

Nasceu muito além

Meu Deus, meu Deus

Na copa da mata

Buzina a cigarra

Ninguém vê a barra

Pois barra não tem

Ai, ai, ai, ai

Sem chuva na terra

Descamba janeiro

Depois fevereiro

E o mesmo verão

Meu Deus, meu Deus

Então o nortista

Pensando consigo

Diz: "isso é castigo

Não chove mais não"

Ai, ai, ai, ai

Apela pra março

Que é o mês preferido

Do santo querido

Senhor são josé

Meu Deus, meu Deus 
Mas nada de chuva

Tá tudo sem jeito

Lhe foge do peito $O$ resto da fé Ai, ai, ai, ai Agora pensando Ele segue outra trilha

Chamando a familia Começa a dizer

Meu Deus, meu Deus

Eu vendo meu burro

Meu jegue e o cavalo

Nós vamos a são paulo

Viver ou morrer Ai, ai, ai, ai

Nós vamos a são paulo

Que a coisa está feia

Por terras alheias

Nós vamos vagar

Meu Deus, meu Deus

Se o nosso destino

Não for tão mesquinho

Pro mesmo cantinho

Nós torna a voltar Ai, ai, ai, ai

$E$ vende seu burro

Jumento e o cavalo

Até mesmo o galo

Venderam também

Meu Deus, meu Deus

Pois logo aparece

Feliz fazendeiro

Por pouco dinheiro

Lhe compra o que tem Ai, ai, ai, ai

Em um caminhão

Ele joga a família

Chegou o triste dia Já vai viajar

Meu Deus, meu Deus A seca terrivel Que tudo devora

Ai, lhe bota pra fora

Da terra natal Ai, ai, ai, ai O carro já corre No topo da serra Olhando pra terra Seu berço, seu lar Meu Deus, meu Deus 
Aquele nortista

Partido de pena

De longe acena

Adeus meu lugar

Ai, ai, ai, ai

No dia seguinte

Já tudo enfadado

E o carro embalado

Veloz a correr

Meu Deus, meu Deus

Tão triste, coitado

Falando saudoso

Com seu filho choroso

Exclama a dizer

Ai, ai, ai, ai

De pena e saudade

Papai sei que morro

Meu pobre cachorro

Quem dá de comer?

Meu Deus, meu Deus

Já outro pergunta

Mãezinha, e meu gato?

Com fome, sem trato

Mimi vai morrer

Ai, ai, ai, ai

E a linda pequena

Tremendo de medo

"Mamãe, meus brinquedo

Meu pé de flor?"

Meu Deus, meu Deus

Meu pé de roseira

Coitado, ele seca

E minha boneca

Também lá ficou

$A i, a i, a i, a i$

E assim vão deixando

Com choro e gemido

Do berço querido

Céu lindo e azul

Meu Deus, meu Deus

O pai, pesaroso

Nos filhos pensando

E o carro rodando

Na estrada do sul

Ai, ai, ai, ai

Chegaram em são paulo

Sem cobre quebrado

E o pobre acanhado

Procura um patrão

Meu Deus, meu Deus 
Só ver cara estranha

De estranha gente

Tudo é diferente

Do caro torrão

Ai, ai, ai, ai

Trabalha dois ano

Três ano e mais ano

E sempre nos planos

De um dia voltar

Meu Deus, meu Deus

Mas nunca ele pode

Só vive devendo

E assim vai sofrendo

É sofrer sem parar

Ai, ai, ai, ai

Se alguma notícia

Das banda do norte

Tem ele por sorte

O gosto de ouvir

Meu Deus, meu Deus

Lhe bate no peito

Saudade de mói

E as água nos olhos

Começa a cair

Ai, ai, ai, ai

Do mundo afastado

Ali vive preso

Sofrendo desprezo

Devendo ao patrão

Meu Deus, meu Deus

O tempo rolando

Vai dia e vem dia

E aquela família

Não volta mais não Ai, ai, ai, ai

Distante da terra

Tão seca mas boa

Exposto à garoa

A lama e o baú

Meu Deus, meu Deus

Faz pena o nortista

Tão forte, tão bravo

Viver como escravo

No norte e no sul

$A i, a i, a i, a i$ 


\section{CONSIDERAÇÕES FINAIS}

A presente dissertação teve o objetivo de realizar uma leitura da depressão masculina com a contribuição dos estudos de gênero, especificamente sobre os estudos das masculinidades. As produções sobre as masculinidades, como objeto de estudo propriamente dito, tem início no final da década de 80 e advêm das lutas feministas e dos estudos sobre as mulheres nos anos 60 .

No primeiro capítulo foi realizado um estudo sistemático sobre depressão masculina nas principais plataformas científicas brasileiras a saber: LILACS e SciELO Brasil. Foram encontradas inicialmente na base LILACS e SciELO Brasil respectivamente 1378 e 386 artigos e foram analisados os artigos que atendiam os critérios de inclusão. Por conseguinte, dezessete pesquisas foram analisadas por tratarem da depressão como foco total (depressão como assunto central e excluídos os artigos que levavam em consideração outras psicopatologias) e primária (depressão não decorrente de doenças físicas). Sobre a fase da vida, onze dos dezessete artigos analisados trataram dos/as velhos/as, três sobre os/as adolescentes, três sobre todas as faixas etárias e somente um sobre a população adulta (único com foco na população masculina).

Dos dezessete artigos, quatorze deles tiveram como foco o caráter epidemiológico e comparativo com as mulheres, em que apenas um teve como foco exclusivamente os homens. Além disso, não houve uma problematização dos próprios sintomas descritos para o diagnóstico masculino o que já foi criticado por autores tais como Shear, Halmi, Widiger e Boyce (2007), Phillips e First (2008), Widiger e First (2008) e Zanello (2014).

Outro ponto importante neste primeiro artigo foi a quase inexistência de pesquisas qualitativas que levassem em consideração a importância de escutar os 
homens, em que somente em duas delas os homens foram entrevistados, ou seja, não foram identificados dentro das suas vivências de sofrimento os pontos pelos quais foram interpelados. Por fim, nenhum desses estudos utilizou a categoria de análise gênero com foco nas masculinidades e somente duas das pesquisas analisadas levaram em consideração a categoria raça/etnia.

Conforme discutido nesta dissertação, por mais que os estudos das masculinidades tenham surgido nos anos 70 e se desenvolvido propriamente dito no final da década de 80 , bem como o racismo seja apontado como fator de sofrimento e risco para a saúde mental, as pesquisas não utilizaram, em sua grande maioria, destas categorias de análise. Além disso, nas pesquisas, os fatores correlacionados à depressão nos homens referem-se também as mulheres, pois foram comparativos. Haja vista que não houve análise específica para cada sexo em nenhum desses estudos, não se pôde apontar grandes achados se levado em consideração o foco nas masculinidades, pois, a literatura não contribuiu na compreensão dos caminhos privilegiados de subjetivação por quais passam as masculinidades.

Posto as limitações da produção de pesquisa sobre a depressão masculina no que tange a quase inexistência de escuta desse público, o segundo capítulo teve como objetivo escutar homens diagnosticados com depressão e compreender, sob a perspectiva dos estudos das masculinidades, como as masculinidades comparecem e quais seriam, então, os fatores envolvidos em seu adoecimento psíquico.

Nos três casos apresentados, evidenciou-se o não cumprimento da masculinidade hegemônica como fonte propiciadora de sofrimento psíquico. Nesse sentido, a masculinidade participa não apenas do processo de subjetivação, mas como fator de risco ou elemento ordálico que coloca em xeque a própria estrutura subjetiva do sujeito e não deixa de ser fonte de sofrimento. 
No primeiro caso visto, o de Luiz, houve a intensificação desse sofrimento em função da faixa etária, aposentado, com grande parte da sua vida já decorrida, nota-se que há um "acerto de contas" com as exigências sexuais e laborativas, as quais Luiz não se acha à altura. Nesse sentido, esse primeiro entrevistado apresentou um discurso marcado pelo pretérito imperfeito, com sofrimento marcado pelo que ele não foi e que poderia ter sido.

No segundo caso, o de Maurício, ele sofre com o não cumprimento das idealizações e "promessas" do curso de medicina com a garantia de status, dinheiro e ao acesso a muitas mulheres propiciadas pelo ideal da masculinidade hegemônica. $\mathrm{O}$ diagnóstico de depressão passa a funcionar como um ponto ambivalente e conflituoso, pois, por um lado, com o tratamento, ele passa a lidar melhor com a cobrança e com a ansiedade frente às exigências das atividades acadêmicas, e por outro lado, a medicação psiquiátrica o leva a "impotência sexual", uma vez que com o uso da medicação sua libido diminui. Porém, por ora, ele se reorganiza psiquicamente, por contar com o apoio da namorada, que passou a ser fator de proteção a sua saúde mental e conseqüentemente contribuiu para a negociação entre as idealizações do curso e da realidade, a qual ele tem feito.

No terceiro caso, o de Eduardo, ele se vê sem capital produtivo, oriundo de família pobre. Muito de seu sofrimento diz respeito à construção de uma carreira. Ele se sentia entre iguais (mesmo status socioeconômico) quando cursava farmácia e já na arquitetura (curso atual) começa no negativo, ou seja, a diferença é transformada em desigualdade pela comparação com colegas que estão mais próximos da masculinidade hegemônica pela vida que levam (acesso a bens simbólicos e capitais). Esse ressentimento passa a incapacitá-lo, e onde ele é convocado a provar, ele acaba por se deprimir e não consegue levar a cabo as atividades acadêmicas. E não apenas isso, o 
acesso a prateleira do amor é limitado (Zanello, 2016) por ele não se achar à altura para se relacionar com colegas da arquitetura por exemplo.

Nos três casos, faz-se necessário destacar o quanto os estudos das masculinidades podem trazer aportes importantes para a compreensão clínica do sofrimento dos homens, quando analisadas e interpretadas essas especificidades gendradas.

Antes de finalizar, é necessário apontar os limites da presente pesquisa: como apontado no primeiro artigo, uma vez que no levantamento e mapeamento realizado quase não houve pesquisas qualitativas, a literatura não contribuiu de forma efetiva para a compreensão do sofrimento psíquico sob o viés de gênero. Assim sendo, torna-se importante a realização de mais pesquisas qualitativas, com a criação de um espaço de escuta clínica, na qual sejam qualificadas as masculinidades e suas diferentes interpelações nas diferentes fases da vida dos homens. Já no segundo artigo, houve uma limitação do número de pacientes, em função da baixa identificação dos mesmos nesse hospital. No entanto, acredita-se que é uma porta aberta para possíveis conversas e futuras pesquisas relacionadas ao cruzamento entre saúde mental e gênero.

Portanto, faz-se necessário o investimento e o desenvolvimento de mais pesquisas que levem em consideração esse viés e conversem com a psicologia clínica, e, talvez, também sejam efetivas e úteis para as políticas públicas de saúde mental e de saúde do homem no Brasil. Cabe finalizar citando a fala de Priore \& Amantino (2013, p.9): “como dizem alguns, os homens não são objeto de estudo original, pois toda a história da humanidade, até periodo recente, foi escrita por eles. Mas é de homens 'sexuados ${ }^{17}$ e não universais que vamos tratar. Homens cuja masculinidade, longe de ser natural, foi socialmente e historicamente construida.

\footnotetext{
${ }^{17}$ Grifo nosso
} 


\section{REFERÊNCIAS ${ }^{18}$}

Brasil, Ministério da Saúde (2008). Política nacional de atenção integral à saúde do homem. Princípios e Diretrizes. Brasília: Ministério da Saúde. Recuperado em 01 de abril, 2015, de http://bvsms.saude.gov.br/bvs/publicacoes/politica nacional atencao saude home $\underline{\text { m.pdf }}$

Butler. J. (2011). Género, Cultura Visual e Performance Antologia Crítica. In A. G. Macedo; F. Rayner (Org.), Actos performativos e constituição de gênero. Um ensaio sobre fenomenologia e teoria feminista (pp.69-88). Universidade do Minho: Húmus.doi:https://repositorium.sdum.uminho.pt/bitstream/1822/23585/1/Genero\%2 0Cultura \%20Visual\%20Performance.pdf

Connell, R. W., \& Messerschmid, J. W. (2013). Masculinidade hegemônica: repensando o conceito. Estudos Feministas, Florianópolis, 21 (1), 241-282. doi: http://www.scielo.br/pdf/ref/v21n1/14.pdf

Figueroa-Perea, J. G. (2016). Algunas reflexiones para dialogar sobre el patriarcado desde el studio y el trabajo con varones y masculinidades. Sexualidade, Salud y Sociedad. Revista Latino Americana, 22, 221-248 doi: http://www.epublicacoes.uerj.br/index.php/SexualidadSaludySociedad/article/view/22451/16119

Flacso Brasil / OPAS-OMS/ ONU Mulheres/ SPM (2015). Mapa da Violência 2015:

Homicídio de Mulheres no Brasil. Recuperado em 01 de junho, 2015 de http://www.mapadaviolencia.org.br/pdf2015/MapaViolencia_2015_mulheres.pdf

Medrado, B., Lyra, J., \& Azevedo, M. (2011). Saúde do homem em debate. In R. Gomes (Org.), 'Eu Não Sou Só Próstata, Eu Sou um Homem!' Por uma política pública de saúde transformadora da ordem de gênero (pp.39-75). Rio de Janeiro: Fiocruz.

Moreno, S. Y. F. (2016). Varones y masculinidades en clave feminista: transcendiendo invisibilidades, ausências y omisiones. Sexualidade, Salud y Sociedad. Revista Latino Americana, 22, 249-277. doi: http://www.epublicacoes.uerj.br/index.php/SexualidadSaludySociedad/article/view/22448/16099

Narvaz, M. G. \& Koller, S. H. (2006). Metodologias Feministas e Estudos de Gênero: Articulando Pesquisa, Clínica e Política. Psicologia em Estudo, Maringá, 11 (3), 647-654. doi: http://www.scielo.br/pdf/pe/v11n3/v11n3a20.pdf

Pereira, P. F. (2014). "Seja Homem": Produção de masculinidades em contexto patriarcal. Curitiba, PR: CRV.

Phillips, K. A. \& First, M. B. (2008). Gênero e Idade - considerações no diagnóstico psiquiátrico: agenda de pesquisa para DSM-V. In W. E. Narrow. et al (Org.), Capitulo 1 Introdução (pp. 3-5). São Paulo: Roca.

\footnotetext{
${ }^{18}$ Referem-se à introdução e as considerações finais da dissertação.
} 
Priore, M. D., Amantino, M. (2013). História dos homens no Brasil In Introdução (p.915). São Paulo: Editora Unesp.

Shear, K., Halmi, K. A., Widiger, T. A., \& Boyce, C. (2007). Age and gender considerations in psychiatric diagnosis: A research agenda for DSM-V. In W.E. Narrow. et al (Org.), Sociocultural factors and gender (pp. 65-79). Washington: American Psychiatric Association.

Swain, T. N. (2014). Histórias feministas, história do possível. Mesa redonda, II Colóquio de Estudos Feministas e de Gênero. Brasília: Universidade de Brasília. doi:http://www.tanianavarroswain.com.br/chapitres/bresil/historia\%20poss\%EDve l.htm

Vigoya, M. V. (2007). Teorías feministas y estudios sobre varones y masculinidades. Dilemas y desafíos recientes La manzana de la discordia, Diciembre, 4, 25-36 http://manzanadiscordia.univalle.edu.co/volumenes/articulos/A2N4/art2.pdf

Welzer-Lang, D. (2004). Masculinidades. In organização M. R. Schpun (Org.), Os homens e o masculino numa perspectiva de relações sociais de sexo (pp.107-128) São Paulo: Boitempo Editorial.

Widiger, T. A. \& First, M. B. (2008). Gênero e Idade - considerações no diagnóstico psiquiátrico: agenda de pesquisa para DSM-V. In W. E. Narrow. et al (Org.), Gênero e Critérios Diagnósticos (pp. 124-134). São Paulo: Roca.

Zanello, V. (2014). A saúde mental sob o viés de gênero: uma releitura gendrada na epidemiologia, da semiologia e da interpretação diagnóstica. In: Zanelo, V. \& Andrade, A. P. M. (Orgs). Saúde Mental e Gênero - Diálogos, Práticas e Interdisciplinaridade (pp. 41-58). Curitiba: Appris.

Zanello, V. (2016). Saúde mental, gênero e dispositivos. In: Dimenstein, M. (Org). Condições de Vida e Saúde Mental em Assentamentos Rurais. São Paulo: Intermeios Cultural. 